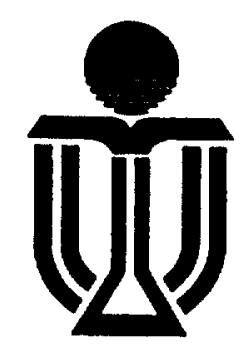

Division of Social Science

The Hong Kong University of Science and Technology

Working Papers in the Social Sciences, No. 36

\title{
The Changing Role of Money in China and Its Implications
}

by

Carsten A. Holz

Division of Social Science

Hong Kong University of Science and Technology

Clear Water Bay

Kowloon, Hong Kong

16 March 1998

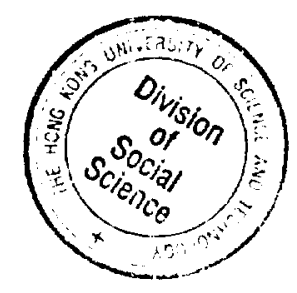




\title{
The Changing Role of Money in China and Its Implications
}

\section{Carsten A. Holz}

\author{
Social Science Division \\ Hong Kong University of Science and Technology \\ Clear Water Bay \\ Kowloon \\ Hong Kong
}

Tel: (852) 2358-7835, -2422

Fax: (852) 2335-0014

E-mail: socholı@usthk.ust.hk

16 March, 1998

The author is grateful for criticism and suggestions provided by Judith Banister, Zhu Xiaodong, the participants of seminars in the Social Science Division at the Hong Kong University of Science and Technology and at the Universities Service Center at the Chinese University of Hong Kong, as well as the participants of the Asian Pacific Rim Experience Session at the 1998 Allied Social Science Association meetings. 


\begin{abstract}
The emergence, development, and economic implications of different financial structures are not well understood. This paper analyzes the emergence and development of the PRC's financial structure since the beginning of the economic reforms. By focusing on the functions of money, of monetary policy, and of financial intermediation, it argues that although agricultural and industrial reforms in the early 1980s have led to significant changes in the financial system, financial liberalization has progressed little since. The creation of new financial institutions and markets throughout the 1990s and the recent abandonment of some of the traditional administrative control instruments, such as the imperative credit plan, do not signify a systemic change as the underlying functions remain constrained. The case of the PRC illustrates that the use of the concept of "financial structure" in deriving implications of financial intermediation for other economic variables, such as economic growth, can be fallacious.
\end{abstract}

Journal of Economic Literature classification: E42, E50, O16, O53, P21, P34 


\section{Introduction}

The role of financial intermediation has been explored in a number of respects, including its effects on investment, public enterprise reform, and economic growth. Most attention has concentrated on the overall link between financial intermediation and economic growth. Market friction such as information and transaction costs are viewed as leading to the establishment of financial markets and financial intermediaries. Financial markets and financial intermediaries in turn perform certain functions affecting other economic variables, in particular economic growth. Empirical studies confirm the link between the development of the financial sector, as manifested in the financial structure, and economic growth.'

How the financial structure of an economy comes about in practice is not well understood and has not been explored in great depth. "We do not have a sufficiently rigorous understanding of the emergence, development, and economic implications of different financial structures" (Levine 1997, 702), where the term "financial structure" covers "the mix of financial contracts, markets, and institutions" (Levine 1997, 703).

In the People's Republic of China (PRC) financial institutions and markets have proliferated rapidly and financial practices have been reformed step by step over the past twenty years since the beginning of the economic reforms in 1978 .

1 Chant (1992) clarifies the conditions under which market friction leads to the emergence of financial intermediation. On the link between financial intermediation and economic growth see, for example, the review articles by Levine (1997), Berthelemy and Varoudakis (1996), Schiantarelli et al. (1993), and Gertler (1988). Empirical studies include Demirgüc and Levine (1996), Thornton 1996, Levine and Zervos (1996), Gregorio and Guidotti (1995), King and Levine (1993a and 1993b), Spears (1992), and Roubini and Sala-i-Martin (1992). 
But we do in fact lack a rigorous understanding of why financial reforms occurred, and of the implications of these financial reforms.

A number of authors describe and analyze socialist financial systems, depict financial transition experiences of individual countries, derive stylized facts on financial development, and make policy recommendations for financial transition and development. ${ }^{2}$ This paper intends to make three contributions. First, I suggest to interpret financial transition in terms of changes in the functions of money, of financial intermediation, and of monetary policy. (See Chart 1, explained in more detail below.) Particular functions of money determine the functions of financial intermediation and of monetary policy, which in turn yield a particular financial structure. This framework allows precise statements on the progress of financial transition.

Second, the framework is applied to the case of the PRC. Financial reform in the PRC has proceeded by lifting one set of restrictions on the functions of money. This led to changes in the functions of financial intermediation and of monetary policy with subsequent changes $n$ the financial structure. However, some restrictions on the functions of money are still in place today; these restrictions prevent the development of purely market-oriented functions of

2 Sigg (1981) and Bank of China International Finance Research Institute (1991) provide descriptions of socialist banking in the case of the former Soviet Union. Analytical approaches include Kloten and von Stein (1993; Part 2, Chapter 4), Hartwig (1987), Dembinski (1988), and, for the case of the PRC, De Wulf (1986), and Cheng (1981).

Cole and Slade (1991) focus on the transition experiences in several developing countries Caprio, Atiyas, and Hanson, eds. (199.4), provide descriptions of financial reform in a number of developed and developing (albeit not transitional) economies with a concluding chapter on lessons and strategies; Miurin (1995) cescribes the banking reform and its effects in Russia.

Bryant (1987; Chapter 2) and Levine (1997) suggest a number of generalizations on how indicators of financial structure change during economic development.

Caprio and Levine (1994) and McKinnon (1993) offer policy recommendations for transitionil economies, Sametz (1991) for China, Claessens (1996) for the choice between radical and gradual banking reform in transitional economies, Sundararajan (1992) for central banking reforms in formerly planned economies, and De Melo and Denizer (1997) for the transition in monetary policy instruments. Brandt and Zhu (1997) explore the impact of the transfer of financial resources to the state-owned sector on economic growth in China. 
financial intermediation and of monetary policy. Since these restrictions are in place for good reason, a simple prescription to lift them appears inappropriate.

Finally, a focus on financial structure in deducing implications of the financial system on other economic variables is dubious. Relating an indicator of financial structure-for instance, financial depth measured as the ratio of savings to GDP - to economic growth may be meaningless. I argue, for example, that financial depth in the PRC is not a measure of the efficiency of the financial system, but of the extent of government debt. Financial structure cannot be viewed out of context with the underlying functions of money, of financial intermediation, and of monetary policy.

The next section lays the groundwork by analyzing how the PRC's pre-reform financial system operated. The third section focuses on the change in one particular function of money in the early 1980s, and the ensuing implications through the functions of financial intermediation and of monetary policy on the financial structure. The fourth section elaborates on recent changes in the financial structure and questions whether any qualitative change in financial intermediation and monetary policy has taken place. The last section concludes on the meaning of a particular financial structure, on the effects of restricted functions of financial intermediation and monetary policy on future financial sector reform in China, and on the role of the financial system in economic transition in general. 


\section{Market friction/ economies of scale \\ 1. Information costs \\ 2. Transaction costs}

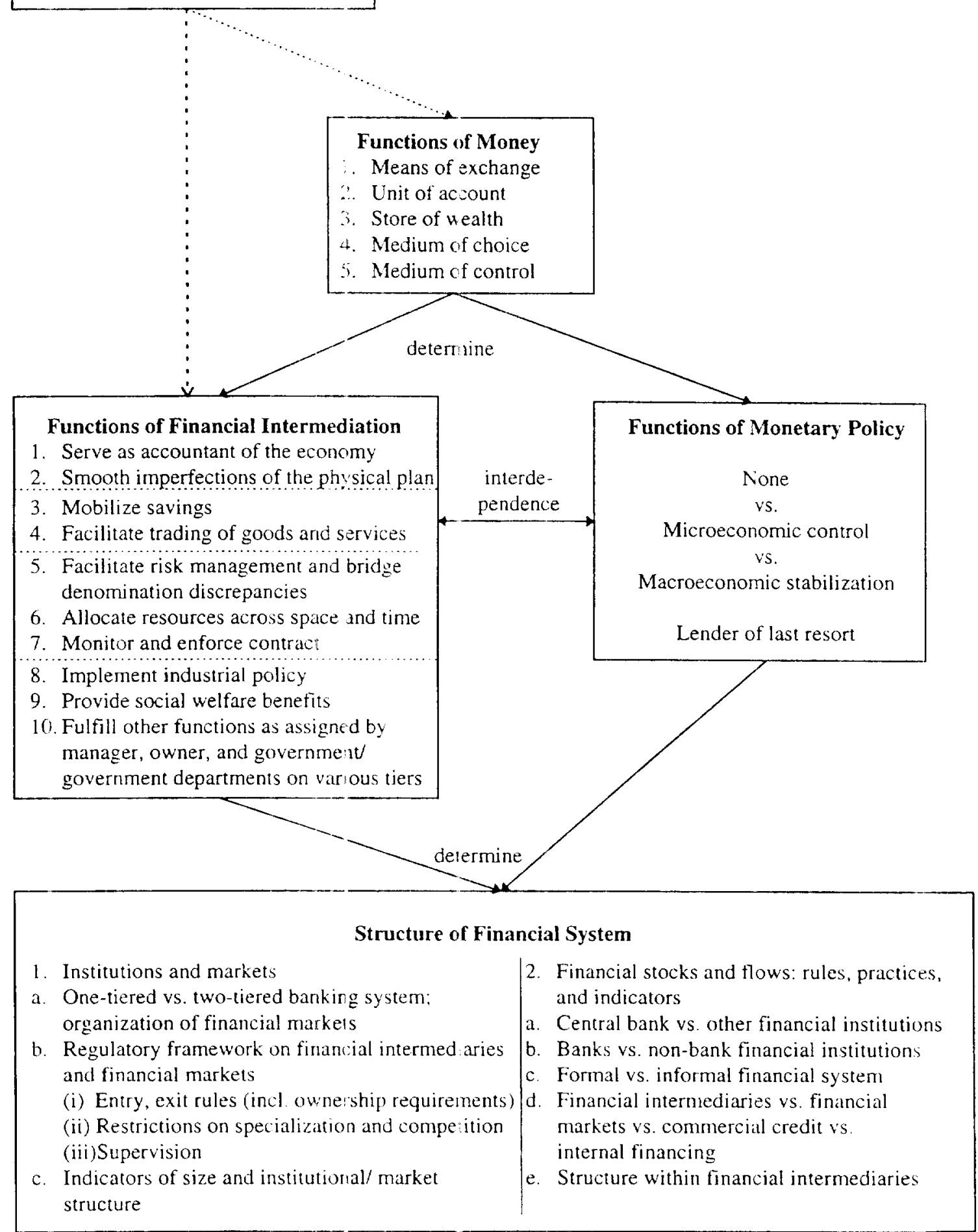

\section{Chart 1. Financial Intermediation}




\section{The Pre-Reform Period Financial Sector: Supplementing the Physically Planned Economy}

China's modern financial system has its origins in the socialist, planned economy. This section explains the producer vs. consumer goods dichotomy inherent to socialist production and derives the implications for the financial sector. ${ }^{3}$ It focuses on the restricted functions of money with their consequences for financial intermediation and monetary policy. How China's modern financial system emerged through a change in these functions is the subject of the next section.

The centrally planned economy is characterized by two distinct circuits, the household circuit on the one hand and the inter-enterprise circuit on the other hand (see Chart 2). In the household circuit enterprises make all wage and salary payments to households in cash according to plan; all enterprises are state-owned and follow nationwide wage and salary scales. Households use their cash receipts to save and to consume (as well as to purchase agricultural producer goods). In the absence of household checking accounts, all withdrawal of household savings deposits and all households purchases are in cash. In the inter-enterprise circuit enterprises buy producer goods from other enterprises. They are not allowed to purchase consumer goods. All payment is made through the transfer of deposits between bank accounts (using 'transfer,' or "book" money); enterprises are subject to rigid cash administration through earmarked accounts in the few instances of cash use, such as for wage payments.

The set of functions of money in this economy differs from the set of functions of money in a market economy in two major respects. (See Table 1.)

Kornai (1979) uses this dichotomy to explain the phenomenon of shortage, but devotes only a few lines to the implications for the financial sector. 
Money in this economy is a medium of control, and it furthermore does not carry the medium of choice function for enterprises. Money fulfills a control function in that each individual monetary transaction is either planned or subject to government supervision. In the household circuit all wage and salary payments are planned. In the inter-enterprise circuit all monetary transactions follow the physical plan. The two circuits are controlled separately. Consumer goods (in the household circuit) can only be bought with cash, producer goods (in the interenterprise circuit) only with transfer money.

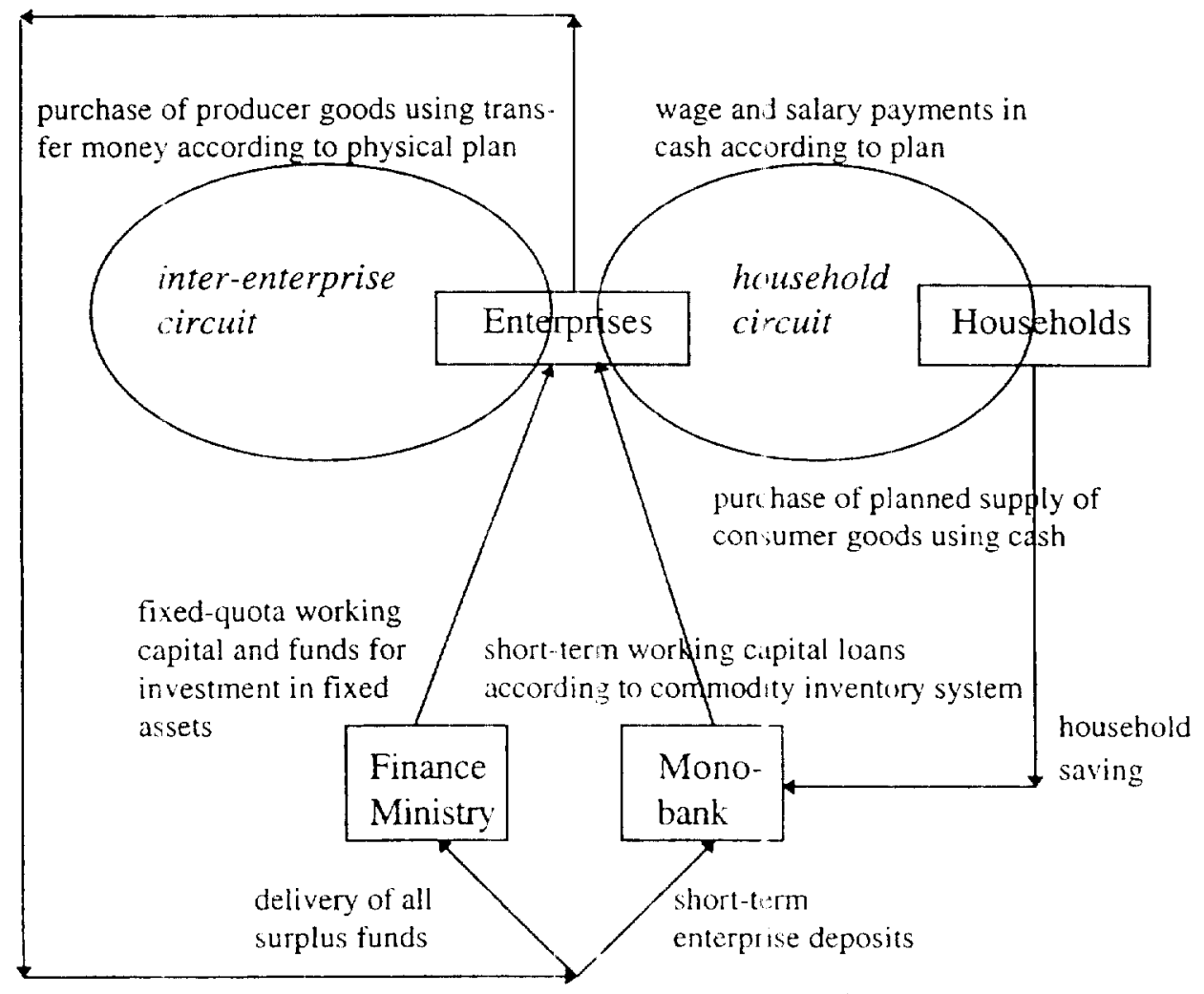

Chart 2. Inter-Enterprise and Household Circuits in the Centrally Planned Economy

The second distinguishing characteristic is the lack of the medium of choice function of money for enterprises. Enterprises have access to their transfer money in bank accounts only if the underlying physical transaction has been approved 
by the relevant state organ or has been included in the physical plan. Enterprises can not decide themselves when to use their money, and what to use it for. ${ }^{4}$

The control function of money and the lack of medium of choice function for enterprises have implications for monetary policy. Wage and salary payments in the household circuit are subject to strict controls, but imbalances between the supply of and the demand for consumer goods may arise as individual household consumption decisions cannot be planned with ultimate precision. However, with household incomes barely above subsistence level, the supply of consumer goods has to meet little more than the-easily predictable — demand for food and everyday household goods. Excess purchasing power is channeled off through the sale of relatively expensive, rationed luxury goods as well as through savings campaigns. ${ }^{5}$ To be on the safe side, prices are state-determined and fixed. In the household circuit there is thus no need for active monetary policy. ${ }^{6}$

In the inter-enterprise circuit imbalances between the demand and supply of producer goods can not arise as long as all transactions scrupulously follow the physical plan. Disturbances in the implementation of the physical plan, however, may lead to imbalances in the physical sphere. They are of no consequence to the

\footnotetext{
4 On the medium of choice function see also Dembinski (1988). A minor, third characteristic is that money is not a store of wealth for enterprises; it may be appropriated by the superordinate ministry or by the finance ministry.

5 Savings in the PRC in the pre-reform period were on a rather small scale, suggesting no major imbalance on the consumer goods market. In 1978 total per capita savings deposits (not distinguishing between rural and urban population) were equal to $16.4 \%$ of average rural per capita annual income and equal to $6.9 \%$ of average urban per capita annual income. For comparison, the percentages for 1995 were $155.2 \%$ and $62.9 \%$. (ZGTJNJ 1996, 279) Per capita currency in circulation in 1978 was equal to $16.5 \%$ of average rural per capita annual income and equal to $7.0 \%$ of average urban per capita annual income; the percentages for 1995 were $41.3 \%$ and 16.7\%. (ZGTJNJ 1996, 69, 279, 614; China Financial Statistics 1952$1987,5)$

6 The monetary or planning authorities coulc have used interest rates on household deposits to influence household consumption decisions, but perhaps there was no need-between 1959 and 1979 interest rates in the PRC were adjusted twice, and then only marginally (ZGJRNJ 1990, 167). (1994)

On repressed inflation in the PRC see, for $\epsilon$ xample, Feltenstein and $\mathrm{Ha}(1991)$ or $\mathrm{Li}$
} 
monetary sphere as long as all prices are state-determined and fixed. Transfer money in the inter-enterprise circuit serves only as "lubricant" of which a sufficiently large amount has to be kept at hand. In the inter-enterprise circuit thus there is likewise no need for active monetary policy.

Since the existence of financial markets would contradict the concept of a planned economy, financial intermediation in this economy is exercised solely by financial intermediaries. Financial intermediaries implement the control function of money in that they serve as accountants of the economy; a glance at the accounts allows an immediate update over fulfillment of the physical plan. The absence of the medium of choice function of money for enterprises is reflected in the financial intermediary's close scrutiny of each individual disbursement of cash (except savings withdrawal by households) and of each transaction using transfer money.

Financial intermediaries smooth imperfections of the planning system by extending short-term working capital loans in accordance with the commodity inventory system. ${ }^{7}$ (The finance ministry supplies all funds for investment in fixed assets as well as fixed-quota working capital.) However, the financial intermediaries have little decision-making authority since the allocation of loans simply follows the instructions of the planning, fiscal, and production hierarchy; ${ }^{8}$ the volume of loans is not constrained by the volume of deposits as the financial intermediaries can refinance themselves at will. ${ }^{9}$

\footnotetext{
7 The commodity inventory system specifies that credit be extended directly to the user in accordance with specific plans and for specific purposes on the basis of material inventories held by the economic unit. Enterprises are required to promptly pay back their loans to the banks when the commodities that we e used to back the credit demand are transferred outside the enterprise. (See De Wulf 1986.) The equivalent concept in market economies is the "real bills principle."

8 Wei and Shao $(1996,40)$ view banks in the pre-reform period PRC as extensions of the government for whom the question of profitability carried no significance.

9 The centrally planned economy thus upholds a very peculiar version of the banking school. Bank branches can autonomously issie transfer money and cash. But rather than being separate banks issuing each their own, competing money - ultimately checked by the
} 
Financial intermediaries finally strive to maintain a high savings rate in order for the government to be able to minimize the production of consumer goods, ${ }^{10}$ and they facilitate trade by providing cash to the household circuit and sufficient amounts of transfer money to the inter-enterprise circuit. (In Chart 1 the first four functions of financial intermediation hold for the centrally planned economy, while functions three through seven hold for a market economy.)

Without the need for monetary policy or the fulfillment of any significant allocative function by financial intermediaries, the banking system is reduced to a monobank, in the PRC the People's Bank of China (PBC). ${ }^{11}$

limitations set through a gold standard or other reserve specie in an open economy-all branches of a singular bank issue the same type of money without reserve or exchange requirement. The absence of the constraints maintained by the banking school does not matter due to the particular functions money plays in the planned economy and due to fixed prices which function as an additional safety mechanism.

The origins of the banking school version adopted in the PRC can be traced back to Karl Marx (Marx 1971; Chapter 34) and to the Soviet banking system (see, for example, Sigg 1981; Chapter 4). Lapavitsas (1994) elaborates further on Marx's concept of money entering into circulation as following logically from reproduction organized by capitalists at exogenously given prices.

10 Walter $(1985,290)$ argues for the case of the PRC that after an unsuccessful credit reform in 1956 "the People's Bank [the only financial intermediary] came to focus primarily on developing its savings operations, which, in contrast to the credit reforms, enjoyed strong local Party support."

11 Between 1969 and 1977 the PBC was furthermore integrated into the Finance Ministry (FM). 


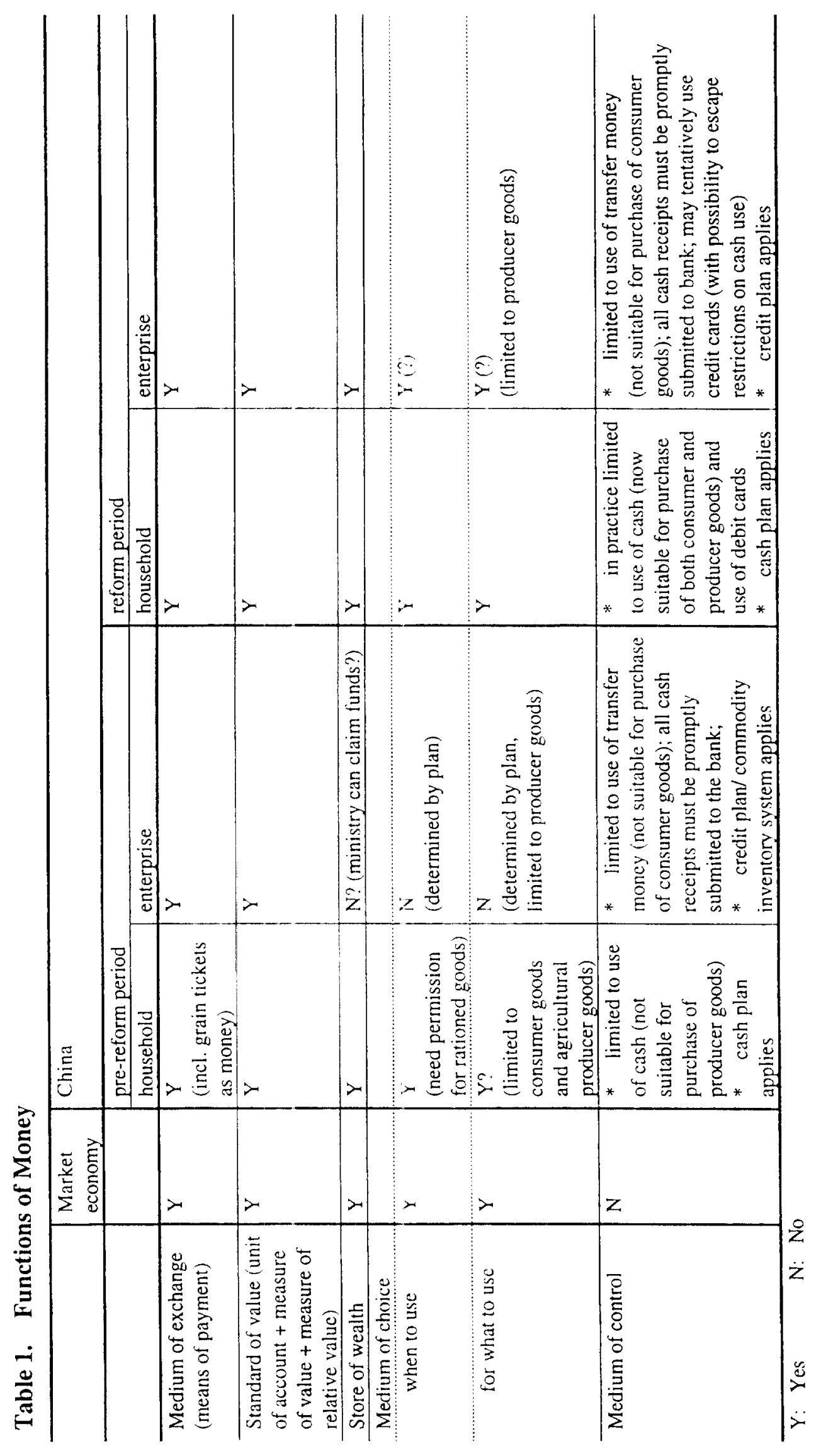




\section{Emergence of China's Modern Financial Structure: Reforms in the Real Economy Lead to Changes in the Role of Money}

The pre-reform period financial system was inherently stable. But once economic reforms in the real sphere began, the monetary system came under pressure to change. ${ }^{12}$ As enterprises were given the right to make their own production and investment decisions, transfer money had to acquire the medium of choice function. (See Table ] above.) This had a number of consequences for the functions of monetary policy and of financial intermediation, and finally the financial structure.

In the early 1980s enterprises began to supplement planned wage and salary payments with bonus payments. The total wage bill increased and became a priori indeterminate. ${ }^{13}$ (See also Chart 3.) Rising household income meant that the share of easily plannable food and everyday household good purchases in total household expenditures declined. The planning bureaucracy subsequently lost partial control over the extent of cash disbursement and withdrawal by the banking system. ${ }^{14}$ The loss of control was exacerbated by the illegal use of cash

12 The secondary literature reviewing the economic reforms and covering the theoretical discussions on economic reforms suggests that reform of the monetary system was not a primary objective throughout the 1980s. For example, Wu (1994) in her book on economic transformation while covering the various economic schools in the PRC throughout the reform period not once refers to the monetary system. Hsu (1991) in his account of the discussions on economic reforms among academics in the PRE during the 1980s likewise does not mention monetary reform.

1.3 The central government tried to maintain an upper limit on bonus payments by levying a steep bonus tax. Bonus payments equaling up to four months of wage and salary payments were free of tax, marginal bonus payments equivalent to a fifth month of wage and salary payments carried a $30 \%$ tax, those equivalent to a sixth month of wage and salary payments a $100 \% \operatorname{tax}$, and those exceeding the equivalent of six months' wage and salary payments a $300 \% \operatorname{tax}$. (SC 84/6/28)

14 For example, while in 1978 easily plannable wages, salary payments and agricultural procurement accounted for $55.1 \%$ of all cash disbursement by state banks, this percentage dropped to $17.0 \%$ by 1995 ; the share of easily plannable goods and services in all cash withdrawal (receipts of cash by state banks) at the same time dropped from 79.2 to $22.1 \%$. 
by enterprises. Imbalances in the household circuit became more likely and could now, with prices successively freed, lead to inflation in the consumer goods market.

The need for active monetary policy in the household circuit arose (while monitoring and enforcement of the cash plan continued). Monetary policy in the household circuit focused on withdrawing excess cash by setting appropriate, centrally determined, nationwide uniform interest rates on household deposits. Between 1978 and 1997 these interest rates were adjusted fourteen times (including two periods of inflation-indexed interest rates on savings deposits of three or more years maturity). ${ }^{15}$

In the inter-enterprise circuit the planning and production bureaucracy gradually lost control over physical transactions. The volume and distribution of transfer money, now a medium of choice, began to matter in that excess transfer money could lead to imbalances in the real sphere. Beginning in 1985, prices for producer goods were partially freed in the dual-track price system; by the early 1990s most producer goods prices were market-determined. Imbalances in the producer goods sector could lead not only to inflation in the producer goods sector but also, through the price of materials and the volume of wages and salaries, to inflation in the consumer goods sector.

The share of the largely unpredictable depositing and withdrawal of savings (both in cash) as share of total cash disbursement and withdrawal rose from 9.6 and $10.7 \%$ in 1978 to 51.1 and 54.3\% in 1995. (See China Financial Statistics 1952-1987; ZGTJNJ 1996.)

15 See Jinrong shibao (Financial 'Times daily newspaper, Beijing) 97/10/28. The first inflation-indexed interest rate period lasted from $88 / 9 / 10$ to $91 / 12 / 1$, while the second began on $93 / 7 / 11$ with the inflation subsidy dropping to zero in May 1997. 


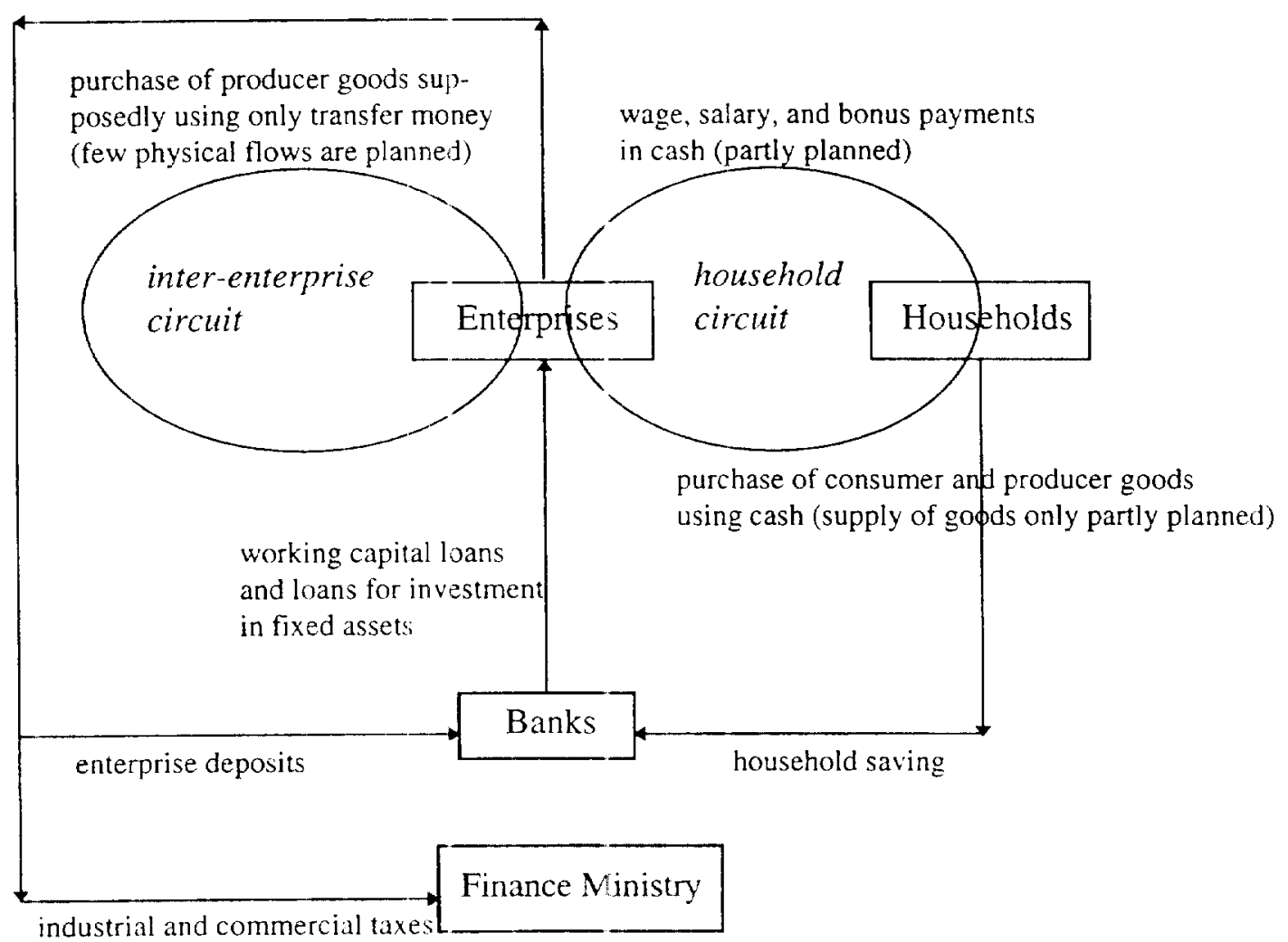

Chart 3. Inter-Enterprise and Household Circuits After 1983/84

The need for active monetary policy in the inter-enterprise circuit arose. As the use of transfer money by enterprises had to be deregulated, it was the extension of additional transfer money (credit) to individual enterprises which became central to monetary policy. ${ }^{16}$ While economic reform led to a reduction of microeconomic control in the real sphere (partial abandonment of the physical

16 The switch in focus from primarily control over deposits to primarily control over credit was helped by a change in the structure of deposits at state banks; the share of deposits by enterprises and government organs dropped continuosly throughout the reform period.

In $1978(1995) 32.5 \%(31.9 \%)$ of all deposits were by enterprises, $30.6 \%(3.5 \%)$ by government departments including the finance ministry, $13.7 \%(55.1 \%)$ by households, $9.7 \%$ $(0 \%)$ were earmarked for capital construction, and $13.6 \%(9.5 \%)$ were rural or other deposits. (1978 information is from China Financial Statistics (1952-1991), 5, and does not include deposits at rural credit cooperatives, which would raise total deposits by $14.6 \%$ but not fit easily with the categories given above. 1995 information is from ZGJRNJ 1996, 429, and covers all financial institutions.) 
plan and price controls), monetary policy took over this microeconomic control task through an elaborate credit plan system.

With transfer money turning into a medium of choice, the financial link between enterprises and superordinate ministry as well as finance ministry had to be severed. Enterprises making their own production decisions could no longer submit all surplus to the finance ministry; a finance ministry receiving less funds could no longer provide enterprise working capital and investment funds. This led to two reforms in the fiscal system. Enterprises were gradually allowed to retain funds through first partial profit retention, and then the 'tax instead of profit delivery' (ligaishui) reform in 1983 to $1985 .{ }^{17}$ At the same time the task of providing working capital and investment funds-if not financed by the enterprise itself - fell to the banking systern in an effort to 'switch from budget appropriations to credit' (bogaidai).

The reforms in the fiscal system implied a much larger volume-and in part a different type- - of business for financial intermediaries. Financial intermediaries came to satisfy $80 \%$ of all working capital needs of enterprises but had no experience with lending criteria except with the 'commodity inventory system' at a time when all monetary flows simply followed implementation of the physical plan. ${ }^{18}$ No decision-making mechanisms at all were in place to determine the allocation of loans to investment projects.

Given this lack of experience in allocating resources and given the perceived need for microeconomic control, now exercised through the monetary system, all

\footnotetext{
17 Nevertheless, until today enterprises arrange ndividual contracts with finance ministries on the corresponding tier substituting tixed profit delivery for tax payments; this is particularly true for large conglomerates under central control and for township and village enterprises below the county level. For details on profit retention by enterprises and the tax instead of profit delivery reform see, for example, Naughton (1985).

18 Enterprises now are supposed to provide at least $20 \%$ of their working capital requirements themselves but in practice rely almost completely on bank credit to supply these funds. The share of enterprises' self-owned working capital dropped from $21.4 \%$ in 1978 to $8.5 \%$ in 1991 (Xie 1992,33 ).
} 
lending authority became subsumed in the credit plan. Lending decisions incorporated industrial policy measures through an elaborate system of preferential access to credit for priority projects and backbone enterprises; working capital loans at times were barely disguised social welfare payments to enterprises starved of funds since the discontinuation of budget appropriations.

Drawing up the credit plan involved not only the financial intermediaries but also the line ministries superordinate to the borrowing enterprise, the finance ministry of the corresponding tier government, and, in the case of investment projects, the planning commission and the economic (and trade) commission hierarchy. The State Planning Commission (SPC) reserved the right of final approval for the nationwide credit plan. While loans thus were extended in name by financial institutions, in practice lending decisions were made outside the financial system in a manner little different from the earlier budget appropriations. ${ }^{19}$ The PBC continued to set all interest rates, subject to State Council approval, at nationwide uniform levels. Financial intermediaries extending loans in accordance with the credit plan drawn up together with or under instructions from other government departments could not be assigned the lending risk, and thus had little incentive to monitor the use of the loans and to enforce repayment.

At the same time as the banking system became inundated with new lending tasks, the PBC exerted strong pressure on financial intermediaries to attract

19 According to Montes-Negret $(1995,31)$, the Industrial and Commercial Bank of China in the early 1990 s could autonomously decide on less than $20 \%$ of its lending. According to Xiao $(1997,371)$, approximately $40 \%$ of all state bank loans in 1991 were "policy loans" (defined in the source as particular lending categories). These loans range from the loans extended to 240 enterprises under the "double-guarantee systenı" (the state guarantees all inputs, the enterprise guarantees all outputs) with no decision-making authority for the bank, to agricultural procurement loans for which the government only determines volume and purpose.

But not all policy loans are explicitly labeled "policy loans." Local governments and lowerlevel tier ministries are participating in, if not making some loan decisions; financial intermediaries may not want to lend to enterprises which do not have borrowing approval from their superordinate ministry. 
savings deposits from households in order to prevent the build-up of inflationary pressures in the consumer goods sector. On the one hand financial intermediaries faced a limit on overall credit plan lending as well as quotas on different types of loans within this overall limit, while on the other hand the PBC provided the financial intermediaries with insufficient refinancing to fulfill these loan quotas and the overall limit. ${ }^{20}$ This led financial intermediaries to exert strong efforts to attract savings deposits. (Financial intermediation thus entered an intermediate stage where the first two functions in Chart 1 were cast aside and the eighth and ninth function rose to prominence, while the fifth through seventh function were not yet developed.)

The changes in the functions of financial intermediation with an increase in the volume and a diversification in the type of banking business led to a change in the institutional structure. As early as 1979 the Agricultural Bank of China $(\mathrm{ABC})$ and the Bank of China $(\mathrm{BoC})$ re-emerged from departments within the $\mathrm{PBC}$ as separate institutions direstly under the State Council. ${ }^{21}$

Since the PBC fulfilled both commercial and central bank functions it increasingly faced difficulties in determining the appropriate volume of transfer money--which now mattered. Furthermore, $\mathrm{ABC}$ and $\mathrm{BoC}$ complained about the preferential treatment of the PBC's own commercial departments when it came

20 The transition in the credit plan system occurred in two stages. At the first stage (1984-86) banks faced both a credit and a deposil plan with refinancing of the difference guaranteed by higher-level branches of the same bank and ultimately the central bank. Deposits attracted in excess of the deposit plan could be turned into working capital loans by the bank branch itself (duocun duodai). Starting 1987 the deposit plan was abandoned, refinancing through the central bank no longer guaranteed, and the credit plan limit became (supposedly) fully binding. 21 The establishment of these "spectal" banks was in part due to the agricultural reforms in $1978 / 79$ and the opening up to foreign trade in the early 1980s, requiring specialized banking services, but also to the fact that they had already existed as separate entities in the years before the cultural revolution. A further reason may have been the desire to avoid concentration of power in an increasingly large and complex financial sector.

On the institutional changes and some of the potential reasons for these changes also see Sheng (1989, 37-40), Jin (1986, 36), Wang and Wang (1989, 74, 86-91), Yu (1987, 254-256), Qin $(1993,47-57)$, and Huang $(1988,113)$. 
to refinancing decisions. Finally, the PBC had little administrative authority over $\mathrm{ABC}$ and $\mathrm{BoC}$ which on the provincial and subprovincial tiers enjoyed a status equal to that of the PBC branches. In September 1983 the PBC was therefore turned into a solely central bank (SC 83/9/17); the commercial banking departments of the $\mathrm{PBC}$ were renamed Industrial and Commercial Bank of China (ICBC). ${ }^{22}$ In 1985 the People's Construction Bank of China (PCBC), formerly a division within the finance ministry in charge of administering the budget appropriations to investment projects, joined the $\mathrm{ABC}, \mathrm{BoC}$, and ICBC as the fourth "special" bank. ${ }^{23}$

22 The State Council justified this move by the need to change the "present situation of dispersed administration and use of funds." A further aspect was the avowed separation of government and enterprises (zhengqi fenkai). The PBC acting as solely a central bank was viewed as an extension of the government controlling special banks operating like enterprises (qiyehucl) through the conduct of (microecononic) monetary policy.

23. In July 1969 the PCBC was integrated into the Finance Ministry (FM). Within the FM it became part of the PBC from June 1970 to April 1972. In 1979 the PCBC supposedly became independent of the FM and directly subordinate to the State Council. (Wei and Shao 1995, 23, 46) The State Council entrusted FM and construction commission with the task of administration (supervision). (Wang and Wang 1989) In 1983 the State Council decided that the PCBC would be under the "business leadership" (yewu lingdao) of the FM while in all matters related to general credit principles, credit policies, and credit plan it would have to follow the instructions of the PBC (SC 83/9/17).

The PCBC was first in exclusive charge of capital construction loans while the ICBC, together with the $\mathrm{ABC}$ and $\mathrm{BoC}$, handled loans for technological updating and transformation as well as working capital loans in their respective sectors of the economy. This division of responsibilities was later abandoned with all special banks obtaining the right to extend every type of loan (within the credit plan). The PCBC' was renamed Construction Bank of China (CBC) in 1996. 


\section{Development of China's Modern Financial Structure: Changes in Financial Structure But Not in Underlying Functions?}

From the mid-1980s to the late 1990s China's financial structure saw a number of momentous changes. However, both cash and transfer money continued to be a medium of control. While the cash plan and supervision over cash flows gradually deteriorated. the volume and distribution of transfer money continued to be in large part determined by the centrally approved credit plan. The concept of two separate moneys was never fully abandoned; the restrictions on the use of cash were retained, as was supervision over the use of transfer money. ${ }^{24}$ This section explores to what extent two very recent financial reform measures represent fundamental changes in the functions of monetary policy and of financial intermediation. The first measture is the switch from credit plan to money supply control in 1998. The second measure is the gradual transition to commercial lending practices in recent years together with the proliferation of financial institutions.

\footnotetext{
24 Following PBC suggestions the ICBC began to offer personal checking accounts in selected cities on a trial basis in 1993. As of end-1996 only Guangzhou showed some success with approximately 20,000 personal checking accounts. (Shaanxi Xinxibao (Shaanxi News) $97 / 1 / 9$ and $96 / 9 / 19$ )

The most recent regulation on the use of cash by enterprises is still in effect (PBC $88 / 9 / 23$ ), although it might not be enforceable throughout the economy-especially for township and village as well as individual-owned enterprises.

To facilitate supervision the Commercial Banking Law specifies that enterprises must keep all their atcounts at one bank only (NPC 95/5/10 Article 48).
} 
Money supply targeting

Since 1996 control over the money supply has supposedly replaced direct credit controls. In 1996 the coverage of the credit plan was limited to the four state commercial banks and in 1998 the credit plan turned "indicative" only. ${ }^{25}$ With this switch in monetary policy tools to targeting a monetary aggregate, and the specification of the PBC's task as currency stabilization (in order to thereby promote economic growth; NPC 95/3/18), the transition from microeconomic control to macroeconomic stabilization appears complete. However, neither has the credit plan been fully abandoned, nor has control over the money supply become an effective channel of macroeconomic control.

The transition from an "imperative" to an "indicative" credit plan for the four state commercial banks reflects little more than an acknowledgment that credit limits in the past few years were not fully implementable. ${ }^{26}$ How imperative the

25 In 1994 the PBC for the first time defined and published various monetary aggregates, and since 1995 the PBC publishes money supply targets. Since 1996 the annual national economic and social development plan no longer contains the targeted credit volume for the upcoming year, although the annual planning conference in late 1996 still set a target for the increase in loans by all financial institutions (Ming Pao (Ming Pao daily newspaper, Hong Kong) 96/12/11).

Ming Pao 96/6/28 reported that for all other commercial banks and credit cooperatives credit limits were abolished in 1996. (Ming Pac did not mention quotas for loans to individual projects.) According to Xie (1997) of the PBC Research Institute, in 1995 the newly issued prudential banking ratios were secondary to the overall credit limit while in 1996 this order was reversed; the credit plan limit was supposedly only relevant for the four state commercial banks. However, Jinrong shibao-t the newspaper published by the $\mathrm{PBC}$ and a number of other financial institutions including the four state commercial banks-as recently as 97/11/30 reportet on how in one particular ccunty ICBC branches were penalized (by the Party cell in the municipal PBC branch) for exceeding their credit plan limits; some branch directors were suspended for three years.

Jinrong shibao 97/12/26 officially announced that the credit plan for the four state commercial banks would starting in 1998 no longer be imperative; however, the plan would be retained for "indicative" guidance.

26 Already in 1986-88, credit limits were merely indicative targets, with overshooting not being penalized. Later on, credit limits were again more strictly enforced. (Mehran 1996, 41) For the discrepancy between credit plan limits and actual credit outstanding see Fan et al. 
"indicative" credit plan will be in the future depends on the practices within each financial institution and on the clout of the PBC as leader of the financial xitong if indicative plan limits were to be widely exceeded. Within each bank, the credit plan is likely to remain imperative as it suits the centralized approval structure in place since 1994; credit decisions with inclusion in the plan occur mainly on provincial tier and above. ${ }^{27}$

Direct control over the money supply consists in practice since 1995 of the passive maintenance of a quasi-pegged exchange rate to the U.S. dollar (with the help of capital account restrictions). Foreign exchange holdings of the $\mathrm{PBC}$ at end-1993 accounted for $11 \%$ of its assets, at end-1995 for $32 \%$, and at the end of the first half of 1997 for $38 \%$. ${ }^{28}$

While pegging the exchange rate suggests the absence of active money supply policy, ${ }^{29}$ the causal chain linking monetary policy measures to bank reserves and then the money supply and output measures furthermore appears outside PBC control and quite unstable. First, the PBC has little influence over financial institutions' reserves. Although since 1987 the $\mathrm{PBC}$ no longer guarantees sufficient refinancing to financial institutions for the latter to fulfill the credit plan on loans to enterprises, PBC Headquarters continue to provide direct annual loans to commercial bank headquarters. ${ }^{30}$ Almost half of all refinancing by 1995

\footnotetext{
$(1993,25)$, and Xie (1997). In the years 1985 to 1996 actual year-end credit outstanding exceeded the plan by between 21 and $109 \%$ (in 1995 and 1985, respectively).

27 See, for example, Jinrong shibao 97/12/20 which states explicitly: "The abandonment of the imperative plan only holds for the commercial bank as a legal person, and does not mean that all tiers of the commercial bank follow deposit-loan ratios and other asset-liability ratios, as if the big bank could be split up into many small banks."

28 For the shares in PBC assets see ZGRMYHT.JJB 1997, no. 3.

29 The of ficial Monetary Policy Committee, mentioned in the PBC Law of 1995 (NPC 95/3/18), was not established until April/July 1997 (the detailed regulation was passed in April, the members appointed in late July). It turned out to be an advisory body only. This leaves any potential money supply decision with the State Council.

30 These loans are usually rolled over when due. Open market operations began in April 1996 and rediscounting has been used since 1986 (up to 1994 on a trial basis), but their volume is negligible compared to direct loans.
} 
went to policy banks according to government instructions; refinancing accounted for 56\% of PBC assets at end-1995, and for $46 \%$ in mid- $1997 .{ }^{31}$ The minimum and safety reserve rates of $13 \%$ and $5-7 \%$, respectively, have remained unchanged since $1988 .^{32}$

Second, money supply targeting may also not be technically feasible as the money multiplier is not very predictable. ${ }^{33}$ The official safety reserve rate is de facto only of guiding nature; for instance during the government's agricultural procurement at harvest time the actual rate may fall far short of the official one. The excess reserve rate and the currency leakage are at present not freely determined by the financial institutions and the public but subject to a number of factors. These include PBC moral suasion, changing regulatory measures, and the degree of implementation of the cash plan. In practice the $\mathrm{PBC}$ may well make do without the money multiplier as it can directly influence the volume of cash through pressure to implement the cash plan, and the volume of deposits by changing the nationwide uniform interes! rates. In addition, the PBC, together with the State Planning Commission and the Ministry of Finance, controls the

Originally, provincial-tier PBC branches also had funds available to extend short-term loans to commercial bank branches. In 1994 all authority was centralized at PBC Headquarters with PBC branches supposedly turning into purely administrative units.

3 At the end of $199538 \%$ of PBC refinancing consisted of direct loans to the policy banks, and $60 \%$ of loans to commercial banks (of which more than fifty-seven percentage points consisted of direct loans, and the other three percentage points of rediscounting). (See ZGJRNJ 1996, 36f.) While the PBC offers practically unlimited refinancing to the Agricultural Development Bank for agricultural procurement - which ranks very highly on the priority list of central government policy makers-it also sells financial bonds on behalf of the State Development Bank to other financial institutions, which may in exchange plead for additional refinancing from the $\mathrm{PBC}$.

32 The meaning of a minimum and safety reserve requirement of together approximately $20 \%$ is unclear in light of a loan-deposit ratio of $75 \%$ with a prohibition for financial institutions to invest in anything much riskier than treasury bonds. (For the state commercial banks the loandeposit ratio only applies to the increases in deposits and loans; on the prudential banking ratios see $\mathrm{PBC}$ 94/2/15.)

33 On the large and unpredictable changes in the money multiplier see China Financial Outlook '96, 22. 
volume of new stocks and bond issues through an annual plan, thus determining the extent of alternative investment channels available to households.

The link between money supply and output finally appears ambiguous in the continued presence of some restrictions on the use of funds and on physical transactions. One example is the direct administrative control over investment at times of overheating through both monetary and physical constraints.

Overall, money supply targeting, although supposedly present-day PBC monetary policy practice, thus appears illusive. Monetary policy consists of (i) maintaining a quasi-peg to the U.S. dollar while guaranteeing certain types of refinancing, (ii) continued control over individual credit (and cash) flows-albeit now through an explicitly "indicative" credit plan (and an equally indicative cash plan), and (iii) continued centrally determined, fixed nationwide interest rates. This mixture of policies implies the continued use of microeconomic control instruments while gaining preliminary experience in targeting monetary aggregates.

\section{Commercial banking}

Throughout the late 1980s and the 1990s financial markets and institutions proliferated. Two stock exchanges were established, money markets began to flourish, and foreign exchange swap centers were united in a centralized foreign exchange trading system under a managed float. Financial institutions multiplied with the establishment of urban credit cooperatives, trust and investment companies, new nationwide as well as regional commercial banks, three development banks, urban cooperative banks, and various non-bank financial 
institutions; rural credit cooperatives became independent of the $\mathrm{ABC} .{ }^{34}$ In recent years the commercial banks have supposedly become "truly" commercial banks, making their own lending decisions subject only to prudential banking ratios. ${ }^{35}$ However, the industrial policy and social welfare functions of financial intermediation have not yet vanished.

Industrial policy and social welfare functions of financial intermediation are reflected in government support on all tiers for state-owned enterprises of the corresponding locale. The government on each tier is responsible for local employment and economic growth. It therefore has a strong interest in channeling loans into the industries and individual enterprises it supports, and into the nearbankrupt state-owned enterprises which must survive in order to not endanger social stability.

Although final loan decisions within all four state commercial banks have since 1994 been recentralized and although the heads of the provincial bank branches are appointed by the bank headquarters, bank branches are still de facto not independent from the same-tier government. ${ }^{36}$ Bank lending decisions (or decisions on including loans in the credit plan) are frequently influenced by the government and/or particular ministries--in exchange, bank personnel in these

3.4 For details on market and institutional changes see, for example, Mehran et al. (1996).

35 See for example, China Financial Outlook '95, 5: "China's commercial banks, in the true sense, have come into being one after another since 1986."

36 Jinrong shibao 97/3/29 carried an example of how a county government tried to pressure a rural joint credit cooperative (lianshe) to extend loans to county enterprises which would then pay taxes to the county government. It threatened (and in part proceeded) to cut off electricity and water supply to the joint credit cooperative, to stage an investigation of the credit cooperative's lending behavior, and to expel the children of the head of the joint credit cooperative from the local school.

After the financial conference of mid-November 1997 it was announced that starting 1998 the provincial heads and municipal mayors would no longer have any authority to issue instructions to bank directors. (Ming Pao 98/1'11)

The establishment of bank branches follows the government administrative structure, and branches may only collect deposits and make loans within their locality. Activities across the borders of the locality must be reported to the PBC. On local financial protectionism see, for example, Ding and Liu (1993). 
cases are absolved of any responsibility for the quality of a loan. ${ }^{37}$ Bank branches can also rely on the local government for support in attracting deposits. ${ }^{38}$

Explicit policy loans are nowadays mainly, but not exclusively, extended by the development banks. ${ }^{39}$ State commercial banks continue to extend loans which are policy loans in all but name. In June 1996 the PBC assigned a first batch of 300 key large and medium-sized state-owned enterprises as well as large and medium-sized state-owned enterprises in seven cities to individual state commercial banks. ${ }^{40}$ The banks are expected to supply sufficient funding. With the proliferation in financial institutions reflecting little more than the creation of

37 Banks are traditionally viewed as secondary in rank to productive enterprises and their superordinate ministries, and thus as service institutions for in particular state-owned enterprises. The question of rank reaches back to the early years of the PRC. See, for example, Walter (1985) on the failure of the 1956 credit reforms and the subsequent low status of the monobank PBC. After the failed reforms, "the PBC continued to supply working capital to enterprises virtually on demand" (p. 289). Until 1990 the PBC was still physically located within the FM.

38 For example, a local government may use campaigns to compel local state employees and enterprises to deposit their money at the local "cocperative fund" (hezuo jijinhui) rather than at a branch of the local state commercial bank. Barks also rely on the local government in matters not directly related to banking business such as housing, schooling, provision of health services, etc.

Other constraints on commercial banking include the obligatory purchase of development bank and government bonds, the obligatory acceptance of deposits of finance ministries and government administrative organs (to be passed on to the PBC), and the handling of special loans for various government departments (often without compensation). Government decisions on planned commodity prices and on a number of other economically relevant factors, such as on the sale of land and on enterprise bankruptcy procedures, have an indirect impact on the quality of bank loans.

39 "Policy loans" are loans extended by a bank using its own funds according to the instructions of an external institution; all risk supposedly rests with the bank. "Special loans" are loans extended by a bank according to the instructions of an external institution using the funds of the external institution; the bank bears no risk.

The Finance Ministry continues to distribute some of its funds as special loans via the PCBC. The PBC, supposed to have ended the practice of extending special loans in 1995, at least has so far not been able to shift its stock of old special loans to another financial institution.

40 See Jinrong shibao 97/1/9. According to the article this "main bank" (zhuban yinhang) system has the advantage that the state sectoral policy can be better implemented, that funds flow to the core enterprises, that it prevents banks from lending only to profitable enterprises, and that banks better understand what is happening, inside the enterprise-not necessarily signs of commercial banking. 
financial institutions attached to lower-level tier governments, the pattern of assigning enterprises to individual financial institutions continues on provincial, municipal, county, and township tier. ${ }^{41}$ The 240 enterprises under the "doubleguarantee" system (the enterprise guarantees output, the government guarantees inputs) continue to receive guaranteed bank loans. By pairing enterprises with banks, government control over the flow of individual loans has been perpetuated independent of the credit plan.

A tradition of banking as accounting and plan fulfillment does not facilitate the development of bank-internal lending decisions according to efficiency criteria. Banks' limited experience in selecting borrowers and in monitoring and enforcing loan contracts is aggravated by limited access to enterprise information. To amend the information deficit the PBC in April 1996 began to issue "credit licenses" to all borrowing enterprises. The credit license contains enterprise information relevant for lending decisions; it must be made available to banks when applying for a loan ${ }^{42}$ But the credit license system has met with strong opposition by enterprises as well as banks which do not want to reveal their past and present lending practices to the $\mathrm{PBC}$. The $\mathrm{PBC}$ itself does not have the staff to sufficiently supervise credit licenses and in practice implementation of the regulation has therefore lapsed.

41 The central government can primarily rely on the four state commercial banks, the provincial government on trust and investment companies as well as regional commercial banks, the municipal government on urban cooperative banks, the county government on rural credit cooperatives (or their successors, the rural cooperative banks), and the township government on rural cooperative funds.

t2 See PBC 95/11/30 and various reports in Jinrong shibao such as on 96/3/31, 96/7/21, and $96 / 12 / 2$

The regulation was first applied in two hundred large and medium-sized cities and then extended by some provinces further down the administrative hierarchy. For the license to be valid, enterprises must submit their balance sheet and profit and loss account for inspection to the PBC annually. When applying for a loan or extending a loan, the bank enters the relevant information in the credit license. 
Commercial banking is not only hampered by the continuation of the practice of policy loans and by the lack of experience and information to make informed lending decisions, but also by the continued central control over interest rates. In the absence of other reliable macroeconomic control instruments, interest rate control is the only effective tool available to the central government to combat inflation in the household circuit (as direct credit control is for the inter-enterprise circuit).

Continued interest rate control has implications for ownership of financial institutions and for competition among financial institutions. During inflationary periods the government maintains a negative interest rate spread to support stateowned enterprises. ${ }^{43}$ Banks are not always fully compensated for these losses. This should prevent the emergence of private financial institutions lending at state-determined interest rates. Perhaps to avoid violations of interest rate regulations which may turn out to be unenforceable with private banks, private banking in China has been outright prohibited. ${ }^{44}$ The absence of non-state banks suggests a lack of competition among financial institutions owned by specific tiers of the state hierarchy and frequently endowed with tier- and locality-specific lending tasks.

Interest rate control also has a direct effect on competition among financial institution. Interest rate liberalization would have a number of consequences. It

\footnotetext{
43 On the negative interest rate spread, see, for example, Montes-Negret (1995, 39). Much of the state-determined interest rate subsidy on deposits was in the end born by the banks themselves. On lower-level tiers bank branches have been (and still are) continuously running losses since the early 1990s. Xiao (1997) shows that interest rate margins in the case of policy loans are not high enough for banks to recover their handling costs.

4. As recently as 1992 the SC agreed to a PBC instruction explicitly stating that "individuals cannot establish banks or non-bank financial institutions and cannot undertake financial business." (PBC 92/12/10). Likewise, Renmin ribao on 6 July 1995 stated that China does not allow the establishment of private banks (according to ZGJRNJ 1996, 17). Newly established nationwide commercial banks such as Huaxia and Minsheng Bank have slightly more complex ownership structures with as owners state-owned enterprises and non-state enterprises under the (state-run) All-China Federation of Industry an 1 Commerce.
} 
would lead to large inter-regional flows, mainly to the coastal regions, which would endanger interior investment plans and production. ${ }^{45}$ Lending to stateowned enterprises at (higher) market rates, allowing financial institutions to cover their costs, would increase the financial burden of enterprises frequently already on the brink of bankruptcy. Interest rate liberalization in the absence of a strict credit plan could finally lead to strong competition for deposits and then reckless lending as banks bear little responsibility for their assets and the PBC serves as lender of last resort. Even if interest rates were not to rise across the board, more recently established financial institutions largely free of (nonperforming) policy loans would be able to offer higher interest rates than, for example, the four state commercial banks; the resulting deposit flow would force the $\mathrm{PBC}$ to increase its refinancing of the latter.

Overall, commercial banking thus is hampered by direct and indirect government influence on lending decisions (the industrial policy and social welfare task functions of financial internediation), by the traditional role of financial institutions in the economy (i.e., the pre-reform functions of financial intermediation), and by contimued central government interest rate control (as indispensable monetary policy tool and means to implement central government industrial and regional policy). The constraints on monetary policy and on commercial banking have implications for the meaning of a particular financial structure, for future financial sector reform in China, and for the role of the financial system in economic transition in general.

45 For example, Shaanxi Province in mid-1993 bitterly complained about the lack of funds to maintain regular production. At the height of the relatively unregulated interbank money market, a large amount of money was flowing from interior provinces to Shanghai. (See, for example, Shaanxi zhengbao (Shaanxi Province Bulletin) \#16/1993, 7.) 


\section{Conclusions}

The restrictions on the functions of money, monetary policy, and financial intermediation suggest that a focus on financial structure in deriving implications of financial intermediation on other economic variables may be misplaced. A particular set of indicators of financial structure may reveal only little of the restrictions on the underlying functions of money, monetary policy, and financial intermediation, and therefore give rise to misinterpretations.

Indicators of the PRC's financial development, such as (i) an increase in financial depth, (ii) the growth of commercial banking relative to lending by the central bank, (iii) the growth of non-bank financial institutions, and (iv) the growth of stock markets, suggest that the PRC follows the typical pattern of developing economies. ${ }^{46}$ This pattern of "financial intermediation" is frequently associated with economic growth. However. a closer look at the underlying functions of monetary policy and financial intermediation in the PRC indicates that this pattern does not necessarily reflect an increase in the efficiency of financial intermediation.

The ratio of total assets of financial intermediaries relative to GDP grew in the PRC because formerly budgetary tasks were switched to the financial system and because no objective constraint on lending (or deposit creation) exists in the monetary sphere. With non-performing loans of the state-owned banking system equivalent to perhaps $80 \%$ of household savings deposits, ${ }^{47}$ an increase in financial depth as measured by the ratio of savings deposits to GDP simply

\footnotetext{
4h See, for example, Levine (1997) or Bryant (1987).

47 A member of the central Party school suggests that "according to today's most conservative estimate," the share of non-performing loans in all bank loans is about 25\%; "some scholars even think this figure to be around 47\%." (Zhou 1995, 1f) At end-1995 a 47\% share of all loans was equal to $82 \%$ of all household savings deposits. (ZGJRNJ 1996, 410)
} 
reflects an increase in government debt. A positive correlation between financial depth and economic growth thus allows no conclusion on the effect of financial intermediation on other economic variables, but indicates a positive effect of a rapid and concealed increase in public debt on economic growth.

The growth of commercial banking relative to lending by the central bank (the second item in the list of stylized facts above) does not reflect a reduction in government-determined lending or an increase in lending efficiency but a rearrangement of institutions, without necessarily a change in the mechanisms determining the supply of loans to enterprises. The growth of non-bank financial institutions is the result of bureaucratic or local government decisions frequently arising from the desire to create local financing sources for local government projects; the growth of these institutions does not necessarily reflect an increase in market-based decisions on monetary flows. The establishment of two stock markets (in Shanghai in 1990 and in Shenzhen in 1991) finally appears little more than a variation on traditional banking as all stock and bond issuing is subject to a central plan and as large variations in prices lead to government interference. Direct control over bank interest rates implies the need for tight control over the interbank money market and the capital market in order to prevent large flows of money between banks and the capital market at times of a discrepancy in bank interest rates and (risk-adjusted) returns in the capital market.

This is not to say that there has been no increase at all in the efficiency of financial intermediation in China. Numerous achievements have been made in improving the efficiency of the banking system in collecting and channeling funds (such as improvements in the payments system and closure of non-profitable bank branches). Reform measures such as the separation of loan approval and loan supervision, the credit license system, and highly publicized central government exhortations to local goveruments not to interfere in lending 
decisions, suggest an attempt to increase the allocative efficiency of funds. ${ }^{48}$ However, the efforts to increase the allocative efficiency of funds have more often than not been thwarted by the need to support state-owned enterprises, by a lack of experience in how to make risk-conscious, independent lending decisions, and by the need to rely on centrally determined interest rates to impose macroeconomic control at times of overheating.

A number of forces suggest a further transition to money supply control and bank-internal lending decisions. First, the extent of non-performing loans is formidable and no longer denied. The task is to stop their growth and then to reduce their extent. Non-performing loans attribute a clear price to the continuation of administrative, microeconomic allocation and control mechanisms. A second force is the limitations of the credit plan itself. The annual (and later quarterly) credit plan with a refined quota system cannot do justice to a complex economy. Since 1994 the widely dispersed authority within the four state commercial banks to allocate credit (with little responsibility) has been recentralized. This recentralization starved lower-level tiers of funds needed to maintain regular production in their enterprises. This in turn has led to the proliferation of financial institutions on all tiers of the state, many of which operate barely within an overall credit limit and the centrally determined interest rate structure. A third force finally is the growth of the informal sector outside all government control. ${ }^{49}$

Several trends are discernible. First, commercial bank decisions on lending to enterprises of a particular tier of government are increasingly localized in

\footnotetext{
48 Some of the attempts at lowering transaction and information costs, such as the credit license system, are based on continued government involvement in lending matters (in this case through the PBC). Gertler and Rose (1994) note the inhibitive influence of continued government participation in the financial system on the functioning of the price mechanism. 49 As little as $50 \%$ of all loans may in the past few years have been extended within the credit plan system. See Qin (1993, 162).
} 
financial institutions owned by that tier. Over the long run it may well turn out that the locality which has opted to allow its banks the greatest scope for profitoriented lending decisions-rather than decisions being subordinated to local industrial policy considerations--is also most successful in furthering local economic growth and increasing local welfare. The local pursuit of growth thus may advance market-oriented financial intermediation..$^{50}$ By localizing the problem of non-performing loans local governments may eventually be forced into responsible behavior.

Second, the PBC turns into an increasingly independent supervisory organization ensuring that local banks fulfill basic requirements (such as the prudential banking ratios). ${ }^{51}$ The $\mathrm{PBC}$ reduces its administrative control over the four state commercial banks and the other nationwide commercial banks and focuses on money supply control through a stable foreign exchange rate while making available refinancing for state priority projects through the central development banks.

Third, the State Council continues to guarantee funding for large and mediumsized state-owned enterprises through explicit main bank relationships and double-guarantee arrangements. The extent of non-performing loans and the continued need for policy loans in the coming years will force the State Council to maintain some form of direct central interest rate control. Such interest rate control may well over time take the shape of increasingly widening interest rate

50 Hong and Cao (1996) elaborate on some aspects of this argument in a context not specific to banking. The dangers of localized banking include the potential lack of risk diversification as well as short-termism by government and bank officials on three-to five-year appointments. s1 The announcement in early 1998 that the PBC would reorganize its first-tier branches from provincial branches into twelve regional branches suggests an attempt to make first-tier PBC branches independent from provincial government influence. However, as of 1998 personnel still move freely between PBC and commercial banks. Personnel overlap between supervisor and supervised still occurs although attempts are being made to avoid such conflicts. (Also see Ming Pao 26 Feb. 1998.) 
bands and extensive interest rate liberalization in those localities where the danger of large inflows of money is small. ${ }^{52}$

The need to realize industrial policy, social welfare, as well as macroeconomic control tasks through the financial system means that the control function of money and the restrictions on monetary policy and financial intermediation will continue to be lifted only gradually. And these restrictions may well be appropriate for an economy still in transition with incomplete markets, an incomplete regulatory framework, a frequently ambiguous property rights allocation, and a still invariably changing political and social environment. Banks may not be ready for an immediate transition to full-blown marketoriented lending, ${ }^{53}$ and neither may be the bulk of state-owned enterprises. Development of a two-track banking system with a regulated and a deregulated sector on the other hand creates the problem of deposit flows and bears the danger of a collapse of the regulated sector.

The middle road consists of a gradual shift to market-oriented monetary policy and commercial lending mechanisms while for the present maintaining the traditional control instruments. The key to success is the introduction of competition through the proliferation of financial institutions and the ever clearer demarcation of policy loans vs. bank-internal lending decisions. Financial institutions cannot be responsible for the reprayment of past and future policy

\footnotetext{
52 Thus high interest rates are tolerated in the semi-formal closed-membership rural cooperative funds

On the latest interest rates and existıng interest rate bands see ZGJRNJ 1977, 493-6, or ZGRMYHTJJB.

53 For example, lending by the four state commercial banks on lower-level tiers has almost completely dried up in 1996 and 1997. The reason is not always a lack of funds within the particular commercial bank xitong. The lack of funds is more likely local-lending decisions in the four state commercial banks have been recentrilized in an attempt to professionalize decision-making and to support primarily large- and medium-sized enterprises. At the same time, bankers on the lowest-level tiers have become more cautious in their lending decisions as lending responsibility increasingly falls on the bankers themselves and the number of creditworthy projects is limited.
} 
loans. However, once they become responsible for their own lending decisions, competition for creditworthy customers arises. At present this frequently means the pursuit of new customers outside the state-owned sector with loans secured through mortgages or guarantors and with legal proceedings in case of default. ${ }^{54}$ As local governments set up social security networks and become willing to abandon unprofitable state-owned enterprises, commercial lending can begin to replace policy loans for all ownership sectors of the economy.

The experience of the PRC bears lessons for other economies in transition. At a first stage of economic reform, allocation of decision-making authority in the real sphere to enterprises necessitates and brings about a change in the functions of money. This change in the functions of money in turn leads to changes in the functions of financial intermediation and of monetary policy with a large effect on the financial structure. As the impact on established bureaucracies is minor and the increase in private income rapid, there is little opposition to this first stage of financial reform. While the real economy faces a physical constraint (no more products can be distributed than have been produced or stored), no such hard constraint exists in the monetary sphere. This allows the delay of painful reforms in the real economy through the accumulation of non-performing loans. At the same time, the state can maintain its administrative, microeconomic control mechanisms over the economy, only now in the monetary sphere. Economic reform appears successful and gains mornentum and support.

However, there are limits to such a "soft" transition. The limits to a soft transition are reached when the extent of non-performing loans becomes politically unacceptable, when credit plan implementation turns unrealistic as real

54 In interviews on the county tier some bankers recalled with relish how they proceeded against individual-owned enterprises which did not repay their loans. Legal action against state-owned enterprises, on the other hand, was still out of question. 
and monetary transactions have become more complex, and when the growth of informal finance outside government control threatens to render any central government control over money supply or credit aggregates powerless. When the second stage of financial reform can no longer be avoided the tasks involve a change in deeply rooted control and perhaps ownership mechanisms throughout the economy, requiring a concerted effort to resolve inconsistencies across the real vs. monetary divide. The crucial question at this point is whether preparations have been sufficient to allow for a final transition without major disruption of income flows and economic growth.

None of the recent China Law Yearbooks in the section on individual legal cases reports on law suits brought by banks. This suggests that hank action against enterprises in the case of loan default does not occur on a large scale. 


\section{References}

Bank of China International Finance Research Institute. Sulian jinrong qishi nian-jianlun meiguo de jinrong (Seventy years of finance in the Soviet Union-with a discussion of finance in the USA). Beijing: Zhongguo shuji chubanshe, 1996.

Berthelemy, Jean Claude, and Aristomene Varoudakis. "Models of Financial Development and Growth: A Survey of Recent Literature," Chapter 1 in Niels Hermes and Robert Lensink, eds., Financial Development and Economic Growth: Theory and Experiences from Developing Countries. London: Routledge, 1996, pp. 7-34.

Brandt, Loren, and Zhu Xiaodong. "Redistribution in a Decentralizing Economy: Growth and Inflation in Reform China." University of Toronto, 1997. Manuscript.

Bryant, Ralph C. International Financial Intermediation. Washington, D.C.: The Brookings Institution, 1987.

Cao Erjie, Li Minxin, and Wang Guoqiang. Xin zhongguo touzi shigang (New China investment annals). Beijing: Zhongguo (aizheng jingji chubanshe, 1992.

Caprio, Gerard, Jr., and Ross Levine. "Reforming Finance in Transitional Socialist Economies." The World Bank Research Observer 9, no. 1 (January 1994): 1-24.

Caprio, Gerard, Jr., Izak Atiyas, and James A. Hanson, eds., Financial Reform: Theory and Experience. Cambridge: Cambridge University Press, 1994.

Chant, Iohn. "The New Theory of Financial Intermediation," Chapter 3 in Kevin Dowd and Mervyn K. Lewis, eds., Current Issues in Financial and Monetary Economics. New York: St. Martin's Press, 1992, pp. 42-65.

Cheng, Hang-Sheng. "Money and Credit in China." Federal Reserve Bank of San Francisco Economic Review (Fall 1981): 19-36.

China Financial Outlook. (People's Bank of China). Beijing: Zhongguo jinrong chubanshe. Various years.

China Financial Statistics 1952-1987. Beijing: China Financial Publishing House, 1989.

Claessens, Stijn. "Banking Reform in Transition Countries." World Bank, 1996. Mantuscript.

Cole, David C., and Betty F. Slade. "Reforrn of Financial Systems," in Dwight Perkins and Michael Roemer, eds., Reforming Economic Systems in Developing Countries. Cambridge, MA: Harvard University Press, 1991, pp. 314-40.

De Melo, Martha, and Cevdet Denizer. "Monetary Policy During Transition: An Overview." The World Bank, Policy Research Working Paper No. 1706, January 1997.

De Wulf, Luc, and David Goldsbrough. "The Evolving Role of Monetary Policy in China." International Monetary Fund Siaff Papers 33, no. 2 (June 1986): 209-42.

Dembinski, Pawel H. "Quantity versus Allocation of Money: Monetary Problems of the Centrally Planned Econonies Reconsidered." Kyklos 41, no. 2 (1988): 281 300 . 
Demirgüc-Kunt, Ash, and Ross Levine. "Stock Markets, Corporate Finance, and Economic Growth: An Overview" The World Bank Economic Review 10, no. 2 (May 1996): 223-39.

Ding Hengjiang and Liu Xiaoqi. "Guanyu difang zhengfu ganyu yinhang jingying huodong de shenceng sikao" (Some profound thoughts on the interference of local governments in bank management). Jingji yanjiu \#12/1993 (Dec. 1993): 45-48, 29.

Fan Gang, Zhang Shuguang, and Wang Limin. "Shuanggui guodu yu 'shuanggui tiaokong' (shang): gaige yilai wo guo hongguan jingji bodong tedian yanjiu" (Double-track transition and double-track adjustment (Part I): a study of the characteristics of the macroeconomic fluctuations since the beginning of the reforms). Jingji yanjiu \#10/1993 (October 1993): 15-26.

Feltenstein, Andrew, and Jiming Ha. "Measurement of Repressed Inflation in China: The Lack of Coordination Between Monetary Policy and Price Controls." Journal of Development Economics 36, no. 2 (Oct. 1991): 279-94.

Gertler, Mark. "Financial Structure and Aggregate Economic Activity: An Overview." Journal of Money, Credit and Banking 20, no. 3 (Part 2, August 1988): 559-88

Gertler, Mark, and Andrew Rose. "Finance, Public Policy, and Growth," Chapter 2 in Gerard Caprio, Jr., Izak Atiyas, and James A. Hanson, eds., Financial Reform:

Theory and Experience. Cambridge: Cambridge University Press, 1994, pp. 13-48.

Gregorio, Jose de, and Pablo E. Guidotti. "Financial Development and Economic Growth." World Development 23, no. 3 (March 1995): 433-48.

Hartwig, Karl-Hans. Monetäre Steuerungsproblme in sozialistischen Planwirtschaften (Problems of monetary control in Socialist planned economies). Stuttgart: Gustav Fischer Verlag, 1987.

Hong Yinxing and Cao Yong. "Jingji tizhi zhuangui shiqi de difang zhengfu gongneng" (Functions of the local government during economic transition). Jingji yanjiu, no. 5 (May 1996): 22-28.

Huang Min. Shehui zhuyi huobi yinhang xue (Socialist money and banking). Wuhan: Wuhan daxue chubanshe, 1988.

Hsu, Robert C. Economic Theories in China, 1979-1988. Cambridge: Cambridge University Press, 1991.

Jin Jiandong. "Wo guo de zhongyang yinhang ji qi zai hongguan jingji guanli zhong de zuoyong" (Chinas central bank and its macroeconomic functions), in Liu Hongru, ed., Zhongguo jinrong shiye de fazhan he jinrong tizhi gaige (The development of finance and financial reform in China). Beijing: Zhongguo jinrong chubanshe, 1986, pp. 35-50.

JRGZZDXB. Jinrong guizhang zhidu xuanbian (Selected financial rules and regulations). Beijing: Zhongguo jinrong chubanshe, two volumes per year.

King, Robert G., and Ross Levine. "Financial Intermediation and Economic Development," Chapter 6 in Colin Mayer and Xavier Vives, eds., Capital Markets and Financial Intermediation. Cambridge: Cambridge University Press, 1993a, pp. 156-89.

King, Robert G., and Ross Levine. "Finance and Growth: Schumpeter Might Be Right." Quarterly Journal of Economics 108, no. 3 (August 1993b): 717-38. 
Kloten, Norbert, and Johann Heinrich von Stein, eds., Geld-, Bank-, und Börsenwesen (Money, banking, and stock markets). 39th edition. Stuttgart: Schäffer-Poeschel, 1993.

Kornai, Janos. "Resource-Constrained versus Demand-Constrained Systems." Econometrica 47, no. 4 (July 1979): 801-19.

Lapavitsas, Costas. "The Banking School and the Monetary Thought of Karl Marx." Cambridge Journal of Economics 18, no. 5 (Oct. 1994): 447-61.

Levine, Ross. "Financial Development and Economic Growth: Views and Agenda." The Journal of Economic Literature 35, no. 2 (June 1997): 688-726.

Levine, Ross, and Sara Zervos. "Stock Market Development and Long-Run Growth." The World Bank Economic Review 10, no. 2 (May 1996): 323-39.

Li Kui-Wai. Financial Repression and Economic Reform in China. Westport, Connecticut: Praeger, 1994.

Marx, Karl. Das Kapital III: Der Gesamtprozess der kapitalistischen Produktion. Berlin: Ullstein Materialien, 1971.

McKinnon, Ronald I. "Macroeconomic Control in Liberalizing Socialist Economies: Asian and European Parallels," Chapter 8 in Albert Giovannini, ed., Finance and Development: Issues and Experiences. Cambridge: Cambridge University Press, 1993, pp. 223-56.

Mehran, Hassanali, Marc Quintyn, Tom Nordman, and Bernard Laurens. "Monetary and Exchange System Reforms in China: An Experiment in Gradualism." Occasional Paper No. 141. Washington, D.C.: International Monetary Fund, 1996.

Miurin. Paolo. "The Banking System, Monetary Policy and Economic Transformation in Russia: 1992-1994." MOCT-MOST 5, no. 1 (Winter 1995): 53-70.

Montes-Negret, Fernando. "China's Credit Plan: An Overview." Oxford Review of Economic Policy 11, no. 4 (1995): 25-42.

Naughton, Barry. "False Starts and Second Wind: Financial Reforms in China's Industrial System." Chapter 9 in Elizabeth J. Perry and Christine Wong, eds., The Political Economy of Reform in Post-Mizo China. Cambridge, Mass.: Harvard University Press, 1985, pp. 223-52.

NPC (National People's Congress).

95/3/18 Zhonghua renmin gongheguo zhongguo renmin yinhang fa (PRC PBC) law). In ZXZYYHSWQS 1995: 309 -13.

95/5/10 Zhonghua renmin gongheguo shangye yinhang fa (PRC commercial banking law). In ZXSYYHSWQS 1995: 1075-82.

PBC (People's Bank of China).

88/9/23 Zhongguo renmin yinhang guanyu yinfa $<<$ Xianjin guanli zanxing tiaoli shishi xize >> (Temporary implementing instructions on the administration of cash). Yinfa \#288/1988. In JRGZZDXB 1988/I: 16-23.

92/12/10 Zhongguo renmin yinhang guanyu qiye, geren bu de banli jinrong yewu de tonzhi (Circular on enterprises and individuals not being allowed to undertake financial business). Yinfa \#284/1992. In JRGZZDXB 1992/: 78.

94/2/15 Zhongguo renmin yinhang dui shangye yinhang shixing zichan fuzhai bili guanli de tongzhi (Circular on the asset-liability ratio management of commercial banks). Yinfa \#38/1994. In JRGZZDXB 1994/I: 25-31. 
95/11/30 Daikuanzheng guanli banfa (Credit License Administration Measures). Yinfa \#322/1995. In JRGZZDXB 1995/I: 141-6.

Qin Chijiang et al. Jinrong tizhi bianqian yu songjin zhuanhuan (Changes in the financial system and the switch from "lose" to "tight" monetary policy). Beijing: Zhongguo caizheng jingji chubanshe, 1993

Roubini, Nouriel, and Xavier Sala-i-Martin. "Financial Repression and Economic Growth." Journal of Development Economics 39, no. 2 (April 1992): 5-30.

Sametz, Arnold W. "The Role of Financial Reform and Development in China's Economic Reform and Development." Journal of Asian Economics 2, no. 2 (Fall 1991): 337-51.

SC (State Council).

83/9/13 Guowuyuan guanyu zhongguo renmin yinhang zhuanmen xingshi zhongyang yinhang zhineng de jueding (State Council decision on the PBC solely functioning as a central bank). In YHFQS 1995: $225 \mathrm{f}$.

$84 / 6 / 28$ (revised 85/7/3) Guoying qiye jiangjinshui zanxing guiding (Temporary regulation on bonus taxes in state-owned enterprises). In ZHRMGHGFLQS vol. 1: $665 \mathrm{f}$.

Schiantarelli, Fabio, Izak Atiyas, Gerard Caprio, Jr., John Harris, and Andrew Weiss. "Credit Where It Is Due? A Review of the Macro and Micro Evidence on the Real Effects of Financial Reform," Chapter 4 in Gerard Caprio, Jr., Izak Atiyas, and James A. Hanson, eds., Financial Reform: Theory and Experience. Cambridge: Cambridge University Press, 1994, pp. 64-81.

Sheng Mujie. Zhongyang yinhang xue (Central banking). Beijing: Zhongguo jinrong chubanshe, 1989.

ShPC (Shaanxi Province Planning Commission). Shaanxi sheng guding zichan touzi guanli wenjian xuanbian (Shaanxi Province selected documents on investment in fixed assets). Shaanxi, 1993.

Sigg, Hans. Grundzuege des sowjetischen Bankwesens: historische Entiwcklung,

Struktur und Aufgaben (Fundamentals of Soviet banking: historical development, structure and tasks). Stuttgart: Haupt, 1981

SPC (State Planning Commission).

84/12/14 Guanyu guojia yusuan nei jiben jianshe touzi quanbu you bokuan gai wei daikuan de zanxing guiding (Temporary regulation on switching all budgetary capital construction investment from budget appropriations to loans). Issued by SPC, FM, and PCBC. In ZHRMGHGFL,QS vol. 1: 839-843.

88/7/19 Guojia jihua weiyuanhui guanyu nengyuan, jiaotong, yuancailiao, jidian qingfang, nongye linye liuge guojia zhuanye touzi gongsi zhengshi chengli de tongzhi (Circular on the offical establishment of the six energy, communications, electronics and textiles, agriculture, and forestry state special investment companies. In SPC 1991: $98 \mathrm{f}$

88/8/4 Guojia jihua weivuanhui guanyu yinfa $<<$ guojia zhuanye touzi gongsi zhangcheng $>>$ de tongzhi (State special investment company statutes). In SPC 1991: 99-105.

SPC (State Planning Commission). Zhonghua renmin gongheguo jihua fagui huibian (Collected laws and regulations on planning in China). Beijing: Zhongguo fazhi chubanshe, 1991. 
Spears, Annie. "The Role of Financial Intermediation in Economic Growth in SubSaharan Africa." Canadian Journal of Development Studies 13, no. 3 (1992): 361 80 .

Sundararajan, V. "Central Banking Reforms in Formerly Planned Economies." Finance \& Development 29, no. 1 (March 1992): 10-13.

Tian Ming, Lian Libin, and Zhao Zhiqin. "Zhenzheng yiyi shang de shangye yinhang hai you duoyuan" (How far away is the truly commercial bank still?). Jinrong yanjiu baogao \#30/1996 (96/10/13).

Thornton, John. "Financial Deepening and Economic Growth in Developing Economics." Applied Economics Letters 3 (April 1996): 243-6.

Walder, Andrew G. "China's Transitional Economy: Interpreting its Significance," in Andrew G. Walder, ed., China's Transitional Economy. Oxford: Oxford University Press, 1996, pp. 1-17.

Walter, Carl E. "Dual Leadership and the 1956 Credit Reforms of the People's Bank of China." The China Quarterly 102 (June 1985): 277-290.

Wang Kehua and Wang Peizhen. Zhongguo huobi yinhang xue (Money and banking in (China). Revised edition. Beijing: Zhongyang guangbo dianshi daxue chubanshe, 1989.

Wei Gongqi, and Shao Youwei. Zhongguo jinrong zuzhi tixi gaige lun (Reform of China's financial structure). Beijing: Zhongguo jinrong chubanshe, 1995.

Wu Yu-Shan. Comparative Economic Transformations: Mainland China, Hungary, the Soviet Union, and Taiwan. Stanford, California: Stanford University Press, 1994.

Xiao Gieng. Chanquan yu zhongguo de jingji gaige (Property rights and China's economic reform). Beijing: Zhonguo shehui kexue chubanshe, 1997.

Xie Kangsheng. "Guanyu quxiao xindai guimo guanli de xianshi tiaojian yu shishi buzhou" (On the actual requirements for and implementary steps of abolishing the administration of the credit volume). Jinrong yanjiu baogao \#10/1997 (97/5/4).

Xie Ping. "Zhongguo jinrong zichan jiegou fenxi" (Analysis of China's financial structure). Jingji yanjiu, \#1 1/1992 (No\%. 1992): 30-7, 13.

YHFQS. Yinhang fa quanshu (Almanac of bank laws). Beijing: Falu chubanshe, 1995.

Yu Ruixiang. Dangdai zhongguo jinrong wenti yanjiu (Contemporary problems in China's financial system). Beijing: Zhongguo jinrong chubanshe, 1987.

ZGJRNJ. Zhongguo jinrong nianjian (Alnanac of China's finance and banking) Beijing: Zhongguo jinrong nianjian bianjibu. Various years.

ZGRMYHTJJB. Zhongguo rennin yinhang tongji jibao (Quarterly PBC statistics). People's Bank of China. Varıous issue::

ZGTJNJ. Zhongguo tongji nianjian (Chiná Statistical Yearbook). Beijing: Zhongguo tongii chubanshe. Various years.

Zhou Tianyong. "Yinhang daizhang he huaizhang shi daozhi shehui dongdang de yinhuan" (Non-performing loans are hidden dangers bringing about social unrest). Jinrong cankao (Jan. 1995): 1-3.

ZHRMGHGFLQS. Zhonghua renmin gongheguo falu quanshu (Collected laws of the PRC). Jilin: Jilin renmin chubanshe. Volumes 1-7.

ZHRMGHGGWYGB. Zhonghua renmin gongheguo guowuyuan gongbao (State Council Bulletin). 
ZXSYYHSWQS. Zui xin shangye yinhang shiwu quanshu (Latest commercial banking manual). Beijing: Zhongguo jinrong chubanshe, 1995.

ZXZYYHSWQS. Zui xin zhongyang yinhang shiwu quanshu (Latest central banking manual). Beijing: Zhongguo jinrong chubanshe, 1995. 


\section{Appendix}

This appendix consists of two tables with additional data to support the arguments made above.

The first table carries indicators on the emergence of China's financial system. In particular, the data cover the bogaidai and ligaishui reforms with their effect on budgetary revenues, budgetary expenditures, bank loans for investment in fixed assets and current assets, and enterprise-specific investment funding. The table also shows some of the changes in cash flows and in savings behavior. It finally documents the expansion of the financial sector.

The second table focuses on the reform years and carries data on the implementation of the credit plan, on the PBC balance sheet structure, on the relative size of financial institutions, and on the relative importance of different financial institutions for changes in loan; outstanding. 


\section{Indicators of Transition in the Monetary System}

\begin{tabular}{|c|c|c|c|c|c|}
\hline & & 1952 & 1955 & 1960 & 1965 \\
\hline \multirow[t]{2}{*}{1} & Gross Domestic Product (b yuan) & & & & \\
\hline & Investment and investment financing & & & & \\
\hline 2 & Total investment in fixed assets (b yuan) & & & & \\
\hline 3 & Sources of funds (b yuan): & & & & \\
\hline 4 & Government & & & & \\
\hline 5 & Banks & & & & \\
\hline 6 & Own & & & & \\
\hline 7 & Foreign & & & & \\
\hline 8 & Orher & & & & \\
\hline 9 & Sources of funds $(\%)$ : & & & & \\
\hline 10 & Government & & & & \\
\hline 11 & Banks & & & & \\
\hline 12 & Own & & & & \\
\hline 13 & Foreign & & & & \\
\hline 14 & Other & & & & \\
\hline 15 & Capital construction (b yuan) & & 10.036 & 38.869 & 17.961 \\
\hline 16 & Sources of funds (b yuan): & & & & \\
\hline 17 & Government & & 9.366 & 30.175 & 16.309 \\
\hline 18 & Banks & & & & \\
\hline 19 & Own & & 0.670 & 8.694 & 1.652 \\
\hline 20 & Foreign & & & & \\
\hline 21 & Other & & & & \\
\hline 22 & Sources of funds $(\%)$ : & & & & \\
\hline 23 & Government & & 93.32 & 77.63 & 90.80 \\
\hline 24 & Banks & & 0.00 & 0.00 & 0.00 \\
\hline 25 & Own & & 6.68 & 22.37 & 9.20 \\
\hline 26 & Foreign & & 0.00 & 0.00 & 0.00 \\
\hline 27 & Other & & 0.00 & 0.00 & 0.00 \\
\hline 28 & Technological updating and transformation (b yuan) & & & & \\
\hline 29 & Sources of funds (b yuan): & & & & \\
\hline 30 & Ciovernment & & & & \\
\hline 31 & Banks & & & & \\
\hline 32 & Gwn & & & & \\
\hline 33 & Foreign & & & & \\
\hline 3.4 & Other & & & & \\
\hline 35 & Sources of funds $(\%)$ : & & & & \\
\hline 36 & Govemment & & & & \\
\hline 37 & Banks & & & & \\
\hline 38 & (lwn & & & & \\
\hline 39 & Foreign & & & & \\
\hline 40 & (ther & & & & \\
\hline
\end{tabular}




\begin{tabular}{|c|c|c|c|c|c|c|c|c|c|}
\hline 1970 & 1975 & 1978 & 1980 & 1982 & 1985 & 1988 & 1990 & 1995 & 1996 \\
\hline & & 362.4 & 451.8 & 529.5 & 896.4 & 1492.8 & 1854.8 & 5847.8 & 6859.4 \\
\hline & & & & & & & & & \\
\hline & & & & 123.04 & 254.319 & 449.654 & 444.929 & 2001.926 & 2297.403 \\
\hline & & & & & & & & & \\
\hline & & & & 27.926 & 40.780 & 41.001 & 38.765 & 62.105 & 62.972 \\
\hline & & & & 17.612 & 51.027 & 92.668 & 87.088 & 419.873 & 457.653 \\
\hline & & & & 71.451 & 153.364 & 290.087 & 232.949 & 1064.787 & 1246.343 \\
\hline & & & & 6.051 & 9.148 & 25.899 & 27.826 & 229.589 & 274.741 \\
\hline & & & & & & & 58.301 & 276.132 & 300.195 \\
\hline & & & & & & & & & \\
\hline & & & & 22.70 & 16.03 & 9.12 & 8.71 & 3.10 & 274 \\
\hline & & & & 14.31 & 20.06 & 20.61 & 19.57 & 20.97 & 19.92 \\
\hline & & & & 58.07 & 60.30 & 64.51 & 52.36 & 53.19 & 54.25 \\
\hline & & & & 4.92 & 3.60 & 5.76 & 6.25 & 11.47 & 11.96 \\
\hline & & & & 0.00 & 0.00 & 0.00 & 13.10 & 13.79 & 13.07 \\
\hline 31.255 & 40.932 & 50.099 & 55.889 & 55.553 & 107.437 & 157.431 & 170.381 & 740.362 & 861.084 \\
\hline 27.273 & 33.558 & 38.921 & 30.011 & 23.248 & 38.118 & 38.166 & 36.359 & 49.167 & 52.438 \\
\hline & & & 4.122 & 7.287 & 18.792 & 28.466 & 37.862 & 164.624 & 193.886 \\
\hline 3.982 & 7.374 & 8.362 & 16.390 & 19.277 & 33.999 & 48.875 & 52.992 & 312.186 & 377.883 \\
\hline & & 2.816 & 5.365 & 5.741 & 7.352 & 21.831 & 22.405 & 105.542 & 123.543 \\
\hline & & & & & 9.176 & 20.092 & 20.762 & 89.998 & 96.500 \\
\hline 87.26 & 81.98 & 7769 & 5370 & 4185 & & & 2134 & & \\
\hline 0.00 & 0.00 & 0.00 & 7.38 & $\frac{41.85}{13.12}$ & $\frac{35.48}{17.49}$ & $\frac{24.24}{18.08}$ & $\frac{21.34}{22.22}$ & $\frac{6.64}{2234}$ & $\frac{6.09}{2252}$ \\
\hline 12.74 & 18.02 & 16.69 & 29.33 & 34.70 & 31.65 & 31.05 & 31.10 & $\frac{22.24}{42.17}$ & $\frac{22.52}{43.88}$ \\
\hline 0.00 & 0.00 & 5.62 & 9.60 & 10.33 & 6.84 & 13.87 & 13.15 & 14.26 & $\frac{7.00}{14.35}$ \\
\hline 0.00 & 0.00 & 0.00 & 0.00 & 0.00 & 8.54 & 12.76 & 12.19 & 12.16 & 11.21 \\
\hline & & & 13.738 & 25.037 & 44.914 & 98.055 & 83.019 & 329.935 & 362.274 \\
\hline & & & & & & & & & \\
\hline & & & 2.418 & 3.295 & 1.969 & 2.702 & 1.756 & 3.832 & 2.958 \\
\hline & & & 3.366 & 6.403 & 18.675 & 37.872 & 26.955 & 80.355 & 83.126 \\
\hline & & & 7.954 & 14.289 & 22.608 & 50.118 & 45.537 & 192.977 & 219.119 \\
\hline & & & 0 & 0.271 & 0.555 & 2.601 & 3.385 & 32.111 & 35.397 \\
\hline & & & & 0.779 & 1.107 & 4.761 & 5.387 & 15.789 & 16.672 \\
\hline & & & & & & & & & \\
\hline & & & 17.60 & 13.16 & 4.38 & 2.76 & 2.12 & 1.16 & 0.82 \\
\hline & & & 24.50 & 25.57 & 41.58 & 38.62 & 32.47 & 24.35 & 22.95 \\
\hline & & & 57.90 & 57.07 & 50.34 & 51.11 & 54.85 & 58.49 & 60.48 \\
\hline & & & 0.00 & 1.08 & 1.24 & 2.65 & 4.08 & 9.73 & 9.77 \\
\hline & & & 0.00 & 3.11 & 2.46 & 4.86 & 6.49 & 4.79 & 4.60 \\
\hline
\end{tabular}




\begin{tabular}{|c|c|c|c|c|c|}
\hline & & 1952 & 1955 & 1960 & 1965 \\
\hline & Bank lending & & & & \\
\hline 41 & Total loans by financial institutions ("banks"; b yuan) & 10.8 & 20.72 & 99.15 & 66.15 \\
\hline 42 & Bank loans for investment in fixed assets (b yuan) & 0 & 0 & 0 & 0 \\
\hline 43 & Bank loans for industrial production (b yuan) & 0.95 & 1.81 & 36.28 & 9.32 \\
\hline 44 & Loans for investment in fixed assed total bank loans (\%) & 0.00 & 0.00 & 0.00 & 0.00 \\
\hline 45 & Loans for industrial production/ total bank loans (\%) & 8.80 & 8.74 & 36.59 & 14.09 \\
\hline 46 & $\begin{array}{l}\text { Change in loans for investment in fixed assets over prevous } \\
\text { year (b yuan) }\end{array}$ & & & & \\
\hline 47 & $\begin{array}{l}\text { Change in loans for industrial production over previous year (b } \\
\text { yuan) }\end{array}$ & & 0.15 & 10.8 & 1.72 \\
\hline 48 & Gross industrial output value of state-owned industry (b yuan) & 14.497 & 27.386 & 148.31 & 126.28 \\
\hline 49 & $\begin{array}{l}\text { Change in gross industrial output value of state-owned } \\
\text { industry over previous year (b yuan) }\end{array}$ & 5.400 & 3.117 & 16.992 & 22.053 \\
\hline 50 & $\begin{array}{l}\text { Gross industrial output value of state-owned industry/ hank } \\
\text { loans for industrial production (\%) }\end{array}$ & 1526.0 & 1513.0 & 408.80 & 1354.9 \\
\hline \multirow[t]{2}{*}{51} & $\begin{array}{l}\text { Change in gross industrial output value of state-owned } \\
\text { industry/ change in loans for industrial production }(\%)\end{array}$ & & 2078.0 & 157.33 & 1282.2 \\
\hline & Government expenditures & & & & \\
\hline 52 & Total government budget expenditures (b yuan) & 17.60 & 26.93 & 65.41 & 46.63 \\
\hline 53 & $\begin{array}{l}\text { Government appropriations for investment in fixed assets (b } \\
\text { yuan) }\end{array}$ & 4.668 & 8.853 & 35.445 & 15.849 \\
\hline 54 & Government working capital appropriations (b yuan) & 1.856 & 3.081 & 6.747 & 2.755 \\
\hline 55 & $\begin{array}{l}\text { Govemment appropriations for investment in fixed asst ts / } \\
\text { total govemment budget expenditures ( } \% \text {; }\end{array}$ & 26.52 & 32.87 & 54.19 & 33.99 \\
\hline 56 & $\begin{array}{l}\text { Govemment appropriations for investrnent in fixed assits / } \\
\text { annual change in loans for investment in fixed assets }(\%)\end{array}$ & & & & \\
\hline 57 & $\begin{array}{l}\text { Government working capital appropriatıons/ total budet } \\
\text { expenditures (\%) }\end{array}$ & 10.55 & 11.44 & 10.31 & 5.91 \\
\hline \multirow[t]{2}{*}{58} & $\begin{array}{l}\text { Govemment working capital appropriations/annual change in } \\
\text { loans for industrial production (\%) }\end{array}$ & & 2054.0 & 62.47 & 160.17 \\
\hline & Government revenues & & & & \\
\hline 59 & $\begin{array}{l}\text { Total government budget revenue (net of government subsidies } \\
\text { to loss-making enterprises; b yuan) }\end{array}$ & 18.37 & 27.20 & 57.23 & 47.33 \\
\hline 60 & Government tax revenue (b yuan) & 9.769 & 12.745 & 20.365 & 20.430 \\
\hline 61 & $\begin{array}{l}\text { Covemment income from enterprises (transfer of } \\
\text { enterprise surplus to the budget, b yuan) }\end{array}$ & 5.727 & 11.194 & 36.584 & $2642 ?$ \\
\hline 62 & $\begin{array}{l}\text { Government revenue from state-owned units (either as } \\
\text { tux or income or in any other form; b yuan) }\end{array}$ & 10.101 & 18.211 & 52.631 & 40.732 \\
\hline 63 & Government subsidies to loss-making enterprises (b yuan) & & & & \\
\hline 64 & $\begin{array}{l}\text { Govemment tax revenue/ total govemment budget revenue } \\
\text { (\%) }\end{array}$ & 53.18 & 46.86 & 35.58 & 43.17 \\
\hline 65 & $\begin{array}{l}\text { Government income from enterprises/total government budget } \\
\text { revenue }(\%)\end{array}$ & 31.18 & 41.15 & 63.92 & 55.84 \\
\hline
\end{tabular}




\begin{tabular}{|c|c|c|c|c|c|c|c|c|c|}
\hline 1970 & 1975 & 1978 & 1980 & 1982 & 1985 & 1988 & 1990 & 1995 & 1996 \\
\hline 105.22 & 148.94 & 189.51 & 249.59 & 330.18 & 630.56 & 1142.50 & 1768.07 & 626286 & 611528 \\
\hline$\overline{0}$ & 0 & 0 & 5.55 & 23.81 & 70.53 & 155.92 & 224.58 & 1014.08 & 1215.36 \\
\hline 24.14 & 29.35 & 35.14 & 42.75 & 51.26 & 98.48 & 208.51 & 355.94 & 912.35 & 1127.83 \\
\hline 0.00 & 0.00 & 0.00 & 2.22 & 7.21 & 11.19 & 13.65 & 12.70 & 16.19 & 19.87 \\
\hline 22.94 & 19.71 & 18.54 & 17.13 & 15.52 & 15.62 & 18.25 & 20.13 & 14.57 & 18.44 \\
\hline & & & $4.7 t_{1}$ & 10.52 & 25.36 & 27.24 & 46.98 & 173.04 & 201.28 \\
\hline 0.74 & 2.68 & 1.72 & 6.44 & 34.9 & 19.62 & 37.82 & 83.48 & 209.93 & 215.48 \\
\hline 185.47 & 260.06 & 328.92 & 391.560 & 432.60 & 630.212 & $\begin{array}{r}1035.12 \\
8\end{array}$ & 1306.38 & 3121.966 & 2836.108 \\
\hline 37.768 & 29.967 & 41.981 & 24.200 & 28.900 & 103.942 & 210.119 & 72.084 & 501.882 & 152.008 \\
\hline 768.31 & 886.05 & 936.02 & 915.9 & 843.93 & 639.94 & 496.44 & 367.02 & 342.19 & 251.47 \\
\hline 5103.8 & 1118.2 & 2440.8 & 375.78 & 82.81 & 529.78 & 555.58 & 86.35 & 239.07 & 70.54 \\
\hline & & & & & & & & & \\
\hline 64.941 & 82.088 & 112.21 & 122.88 & 123.00 & 200.425 & 249.121 & 308.359 & 682.372 & 793.755 \\
\hline 29.836 & 32.696 & 45.192 & 34.636 & 26.912 & 55.456 & 49.476 & 54.739 & 78.922 & 90.744 \\
\hline 3.123 & 4.184 & 6.660 & 3.671 & 2.363 & 1.430 & 0.959 & 1.090 & 3.480 & 4.293 \\
\hline \multirow[t]{2}{*}{45.94} & 39.83 & 40.27 & 28.19 & 21.88 & 27.67 & 19.86 & 17.75 & 11.57 & 11.43 \\
\hline & & & 727.65 & 255.82 & 218.68 & 181.63 & 116.52 & 45.61 & 45.03 \\
\hline$\overline{4.81}$ & 5.10 & 5.94 & 299 & 1.92 & 0.71 & 0.38 & 0.35 & 0.51 & 0.54 \\
\hline 422.03 & 156.12 & 387.21 & 57.00 & 6.77 & 7.29 & 2.54 & 1.31 & 1.66 & 1.99 \\
\hline & & & & & & & & & \\
\hline 66.290 & 81.561 & 113.23 & 115.99 & 121.23 & 200.482 & 235.724 & 293.710 & 624.220 & 740.799 \\
\hline 28.120 & 40.277 & 51.928 & 57.170 & 70.002 & 204.079 & 239.047 & 282.186 & 603.804 & 690.982 \\
\hline 37.897 & 40.020 & 57.199 & 43.526 & 29.647 & 4.375 & 5.112 & 7.830 & 0 & 0 \\
\hline \multirow[t]{2}{*}{58.239} & 70.255 & 98.479 & 100730 & 103.29 & 155.627 & 168.796 & 209.510 & 444.104 & \\
\hline & & & & & 50.702 & 44.646 & 57.888 & 32.777 & 33.74 \\
\hline$\overline{42.42}$ & 49.38 & 45.86 & 49.29 & 57.74 & 101.79 & 101.41 & 96.08 & 96.73 & 93.28 \\
\hline 57.17 & 49.07 & 50.52 & 37.52 & 24.45 & 2.18 & 2.17 & 2.67 & 0.00 & \\
\hline
\end{tabular}




\begin{tabular}{|c|c|c|c|c|c|}
\hline & & 1952 & 1955 & 1960 & 1965 \\
\hline 66 & $\begin{array}{l}\text { Government revenue from state-owned units/total govemment } \\
\text { budget revenue }(\%)\end{array}$ & 54.99 & 66.95 & 91.96 & 86.06 \\
\hline \multirow[t]{2}{*}{67} & $\begin{array}{l}\text { Government revenue from state-owned urits net of } \\
\text { government subsidies to loss-making enterprises/total } \\
\text { government budget revenue }(\%)\end{array}$ & 54.99 & 66.95 & 91.96 & 86.06 \\
\hline & Cash flows & & & & \\
\hline 68 & Share in cash disbursement from state banks (in \%) & & & & \\
\hline 69 & Salaries and wages, agricultural procurement & & 57.5 & 46.2 & 61.0 \\
\hline 70 & Savings withdrawal & & 11.8 & 19.6 & 87 \\
\hline 71 & Share in cash receipts of state banks (in $\%$ ) & & & & \\
\hline 72 & Sale of commodities and services & & 72.3 & 64.5 & 77.5 \\
\hline \multirow[t]{2}{*}{73} & Savings depositing & & 12.1 & 20.7 & 9.5 \\
\hline & Urban income & & & & \\
\hline 74 & Number of staff and workers (m persons) & 16.03 & 21.62 & 59.69 & 49.65 \\
\hline 75 & Wages of staff and workers (b yuan) & 6.83 & 10.88 & 29.67 & 28.23 \\
\hline 76 & Living cost index of staff and workers $(1950=100)$ & 115.5 & 123.5 & 128.8 & 139.0 \\
\hline 77 & Wages per staff and worker in 1950 yuan & 368.90 & 407.48 & 385.92 & 409.05 \\
\hline \multirow[t]{2}{*}{78} & Wages of staff and workers/ GDP (\%) & & & & \\
\hline & Employment in finance & & & & \\
\hline 79 & Total employment (million persons) & 2072.9 & 223.28 & 258.80 & 2867.0 \\
\hline 80 & Employment in banking and insurance (ten thousand persons) & & & & \\
\hline \multirow[t]{2}{*}{81} & Share of banking and insurance in total employment (in $\%$ ) & & & & \\
\hline & Size of state banks & & & & \\
\hline 82 & State banks & & & & \\
\hline 83 & Number of branches & & & & \\
\hline 84 & Employment (persons) & & & & \\
\hline 85 & Assets (b yuan) & 11.88 & 21.87 & 96.02 & 66.22 \\
\hline 86 & Loans (b yuan) & 10.80 & 20.42 & 96.92 & 64.74 \\
\hline 87 & Deposits (b yuan) & 9.33 & 14.17 & 45.98 & 48.10 \\
\hline 88 & Assets/GDP (\%) & & & & \\
\hline 89 & Loans/ GDP $(\%)$ & & & & \\
\hline \multirow[t]{2}{*}{90} & Loans/Deposits (\%) & 115.76 & 144.11 & 210.79 & 134.59 \\
\hline & Size of all financial institutions & & & & \\
\hline 91 & Assets (b yuan) & 11.88 & 22.48 & 100.33 & 70.50 \\
\hline \multirow[t]{2}{*}{92} & Assets/GDP $(\%)$ & & & & \\
\hline & Savings & & & & \\
\hline 93 & Total household savings deposits (b yuan) & & 1.99 & 6.63 & 6.52 \\
\hline 94 & Total household savings deposits/ GDP (\%) & & & & \\
\hline 95 & Annual change in households savings deposits (b yuan) & & 0.40 & -0.20 & 0.97 \\
\hline 96 & Annual change in household savings deposits/ GDP $(\%)$ & & & & \\
\hline
\end{tabular}




\begin{tabular}{|c|c|c|c|c|c|c|c|c|c|}
\hline 1970 & 1975 & 1978 & 1980 & 1982 & 1985 & 1988 & 1990 & 1995 & 1996 \\
\hline 87.85 & 86.14 & 86.98 & 86.84 & 85.20 & 77.63 & 71.61 & 71.33 & 71.15 & \\
\hline 87.85 & 86.14 & 86.98 & 86.84 & 85.20 & 52.34 & 52.67 & 51.62 & 65.89 & \\
\hline & & & & & & & & & \\
\hline & & & & & & & & & \\
\hline 57.4 & 55.2 & 55.1 & 55.4 & 52.3 & 46.1 & 34.7 & 33.9 & 17.0 & 14.6 \\
\hline 0.0 & 8.9 & 9.6 & 107 & 12.9 & 17.7 & 30.1 & 33.3 & 51.1 & 55.1 \\
\hline & & & & & & & & & \\
\hline 78.2 & 79.7 & 79.2 & 742 & 68.7 & 57.9 & 45.8 & 38.7 & 22.1 & 20.2 \\
\hline 0.0 & 9.3 & 10.7 & 14.3 & 16.0 & 22.6 & 33.8 & 40.2 & 54.3 & 57.0 \\
\hline 62.16 & 81.98 & 94.99 & 104.44 & 112.81 & 123.58 & 136.08 & 140.59 & 149.08 & 148.45 \\
\hline 33.43 & 46.35 & 56.89 & 77.24 & 88.20 & 138.30 & 231.62 & 295.11 & 810.00 & 908.00 \\
\hline 137.8 & 139.5 & 144.7 & 158.5 & 165.8 & 194.4 & 273.1 & 321.7 & 483.9 & 513.4 \\
\hline 390.28 & 405.29 & 413.89 & 466.60 & 471.56 & 575.68 & 623.25 & 652.50 & 1122.82 & 1191.38 \\
\hline & & 15.70 & 17.10 & 16.66 & 15.43 & 15.52 & 15.91 & 13.85 & $13.2:$ \\
\hline 3443.2 & 3816.8 & 4015.2 & 4236.1 & 4529.5 & 4987.3 & 5433.4 & 6390.9 & 6794.7 & 6885.0 \\
\hline & & 76 & 99 & 113 & 138 & 194 & 218 & 276 & 292 \\
\hline & & 1.89 & 2.34 & 2.49 & 2.77 & 3.57 & 3.41 & 4.06 & 4.24 \\
\hline & & & & & & & & & \\
\hline & & & & & & & & & \\
\hline & & & & 48925 & 58364 & 98076 & 116947 & 160142 & 161113 \\
\hline & & & & 704077 & 924828 & 1204009 & 1421724 & 1922984 & 2005244 \\
\hline 104.66 & 148.47 & 187.65 & 262.43 & 361.84 & 637.45 & 1235.90 & 1821.27 & 5398.903 & 6557.270 \\
\hline 103.34 & 146.27 & 185.00 & 241.43 & 318.06 & 590.56 & 1142.50 & 1654.13 & 3939.340 & 4743.452 \\
\hline 70.43 & 97.51 & 113.45 & 166.12 & 236.99 & 426.49 & 823.67 & 1302.93 & 3878.260 & 4959.339 \\
\hline & & 51.78 & 58.09 & 68.34 & 71.11 & 82.79 & 98.19 & 92.32 & 95.60 \\
\hline & & 51.05 & 53.44 & 60.07 & 65.88 & 76.53 & 89.18 & 67.36 & 69.15 \\
\hline 146.73 & 150.01 & 163.07 & 145.33 & 134.21 & 13847 & 138.71 & 126.95 & 101.57 & 95.65 \\
\hline 112.30 & 161.98 & 204.25 & 289.66 & 400.83 & 709.94 & 1339.63 & 1976.60 & 7309.658 & 8951.983 \\
\hline & & 56.36 & 64.11 & 75.70 & 79.20 & 89.74 & 106.57 & 125.00 & 130.51 \\
\hline & & & & & & & & & \\
\hline 7.95 & 14.96 & 21.06 & 39.95 & 67.54 & 162.26 & 382.22 & 711.98 & 2966.23 & 3852.08 \\
\hline & & 5.81 & 8.84 & 12.76 & 18.10 & 25.60 & 38.39 & 50.72 & 56.16 \\
\hline 0.36 & 1.31 & 2.90 & 11.85 & 15.17 & 40.79 & 74.08 & 192.34 & 814.35 & 88585 \\
\hline & & 0.80 & 2.62 & 2.86 & 4.55 & 4.96 & 10.37 & 13.93 & 12.91 \\
\hline
\end{tabular}


Sources:

Gross Domestic Product: ZGTJNJ 1997, 42; ZGT JZY 1997, 9.

Household savings deposits (and changes therein) ZGJRNJ 1997, 466.

Total employment: ZGTJNJ 1997, 96; ZGTJNJ 1992, 97.

Number of staff and workers: ZGJTNJ 1997, 100: ZGTJNJ 1992, 97.

Total wages of staff and workers: ZGTJNJ 1997, 120; ZGTJNJ 1992, 119.

Living cost index of staff and workers: ZGTJNJ 1997, 267; ZGTJNJ 1992, 236. In the early 1990 s the "Living cost index of staff and workers" was presumably renamed "General consumer price index of urban areas" - the statistics under the old title available up to 1991 and the statistics under the new title availiable starting 1978 are identical in the overlapping years.

Investment in fixed assets and sources: ZGTJNJ 1997, 151. Investment in fixed assets consists of investment by state-owned units, collective-owned units, individual- and privately owned units, foreign units, and others. Investment by state-owned units consists of capital construction (new investment), technological updating and transformation, real estate investment, and others. When the entry for "other" sources of funds is zero, other sources of funds have been included in the original stat stics in "own" funds.

Capital construction and sources: 1985-96: ZGTJNJ 1997, 155f; 1955-82: ZGGDZCTZTJZL 1950-1985, 59 .

Technological updating and transformation: 1985-96: ZGTJNJ 1997, 174f; 1980-82: ZGGDZCTZTJZL 1950-1985, 216. (Individual sources of funding do not fully add up to the total in the original statistics.)

Total loans by financial institutions, loans for investment in fixed assets, and loans for industrial production: 1995-96, and 1990 total loans: ZGJRNJ 1997, 464; 1988 and 1990 otherwise: ZGJRNJ 1991, 41; 1955 -1985: China Financial Statistics (1952-1991): 8-11, 61-62. Financial institutions include all financial institutions in operation at the time.

Gross industrial output value: 1988-96: ZGTJNJ 1997, 415; 1952-85: ZGTJNJ 1992, 406. A statistical break occurs between 1905 and 1996. (The absolute 1996 data is not comparable to prior absolute data. The increase in 1996 is based on comparable 1995 data.)

Government budget expenditures: 1970-96: ZGTJNJ 1997, 235, 241, 243; 1952-65: ZGTJNJ $1992,215,221$. Total government expenditure; do not include repayment of principal and interest on domestic and foreign deht, nor foreign loans used to finance capital construction.

Government budget revenue: 1970-96: ZGTJNJ 1997, 235, 238f; 1952-65: ZGTJNJ 1992, $215,217 \mathrm{f}$.

Cash: China Financial Statistics (1952-1987), 39-48; ZGTJNJ 1997, 623.

Assets of all financial institutions: 1996: ZGJR 3/97, 29-31. 1995: ZGJR 3/96, 29f. 1990 and 1988: ZGJRNJ 1996, 434; ZGJRNJ 1994, 5541. 1952-1985: China Financial Statistics (1952-1991), 3-6, 61f. All financial institutions include the state banks (of which the CBC since 1982), other commercial banks (since 1990), rural credit cooperatives, urban credit cooperatives, and trust and investment corpora ions (since 1988). Since assets figures for rural credit cooperatives are not ava lable they nave been approximated by deposits (which exceed loans). This problem does not arise for the years 1990 and 1988 as balance sheet data for state banks plus rural credit cooperatives (together) is available.

Employment in banking and insurance: ZGTJNJ 1997, 98f; ZGTJNJ 1990, 114.

State banks:

Branches and employment: 1982-1985: China Financial Statistics (1952-1991): 84; although the source does not define "state banks" these are likely to include only the 
four state commercial banks. 1988-1996 ZGJRNJ 1997, 591; "state" banks include other state commercial banks. The 1985 data in the two sources are identical.

Assets, loans, and deposits: 1996: ZGJR 3/97, 29 ("state banks" includes the PBC, the development banks, the four state commercial banks, the Bank of Communications, CITIC Industrial Bank, and postal savings offices). 1995: ZGJR 3/96, 29 ("state banks" are defined as in the year 1996), 1988 and 1990: ZGJRNJ 1996, 435 ("state banks" are defined as in the year 1996 but without explicitly mentioning postal savings offices). 1952-1985: China Financial Statistics (1952-1991): 3-6, 8-11.

Sources only used in this table:

ZGTJZY. Zhongguo tongji zhaiyao (China Statistical Survey). Beijing: Zhongguo tongji chubanshe. Various years.

ZGGDZCTZTJZL. Zhongguo guding zichan touzi tongji ziliao 1950-1985 (China investment in fixed assets statistics 1950-1985). Beijing: Zhongguo tongji chubanshe, 1987. 


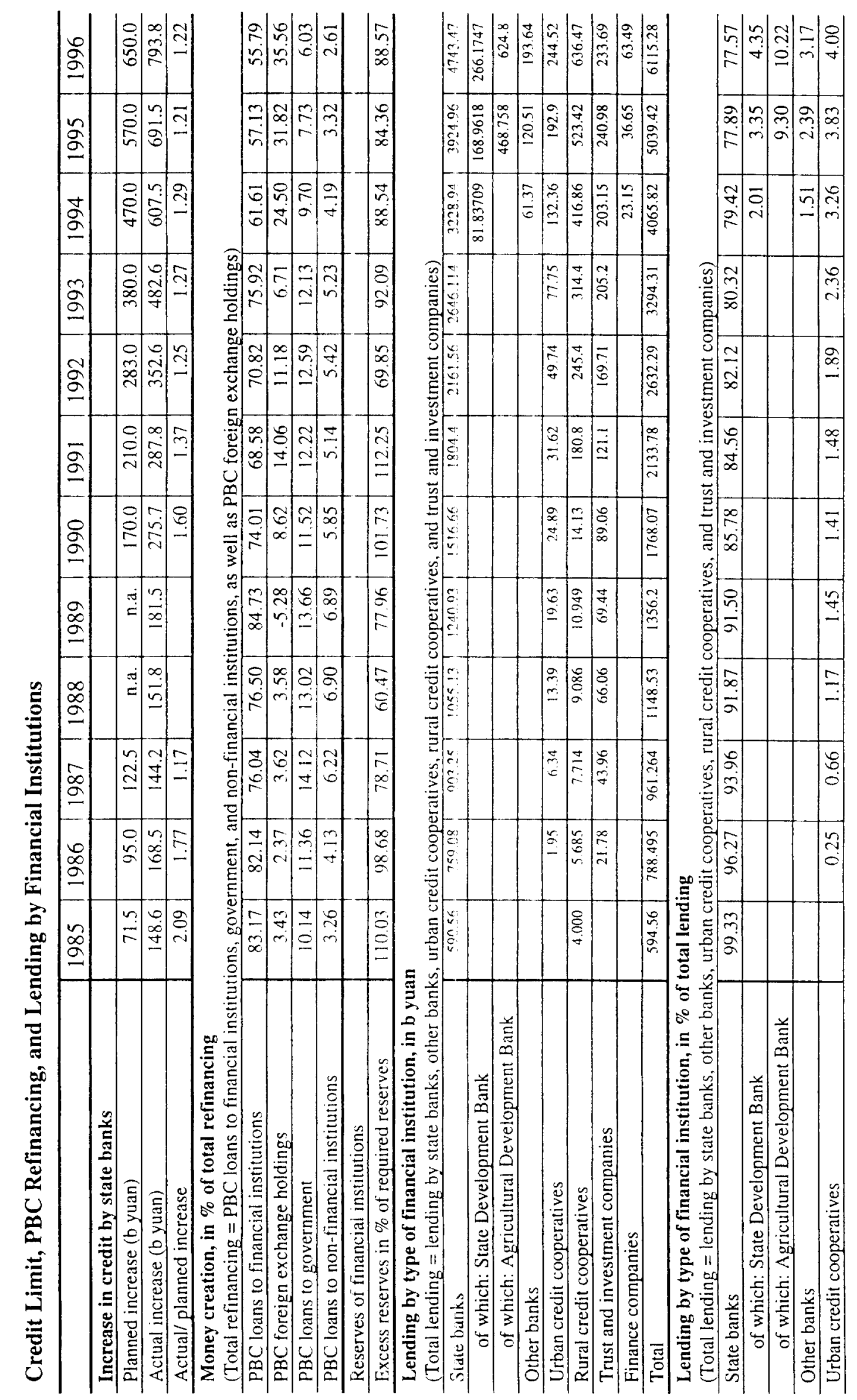




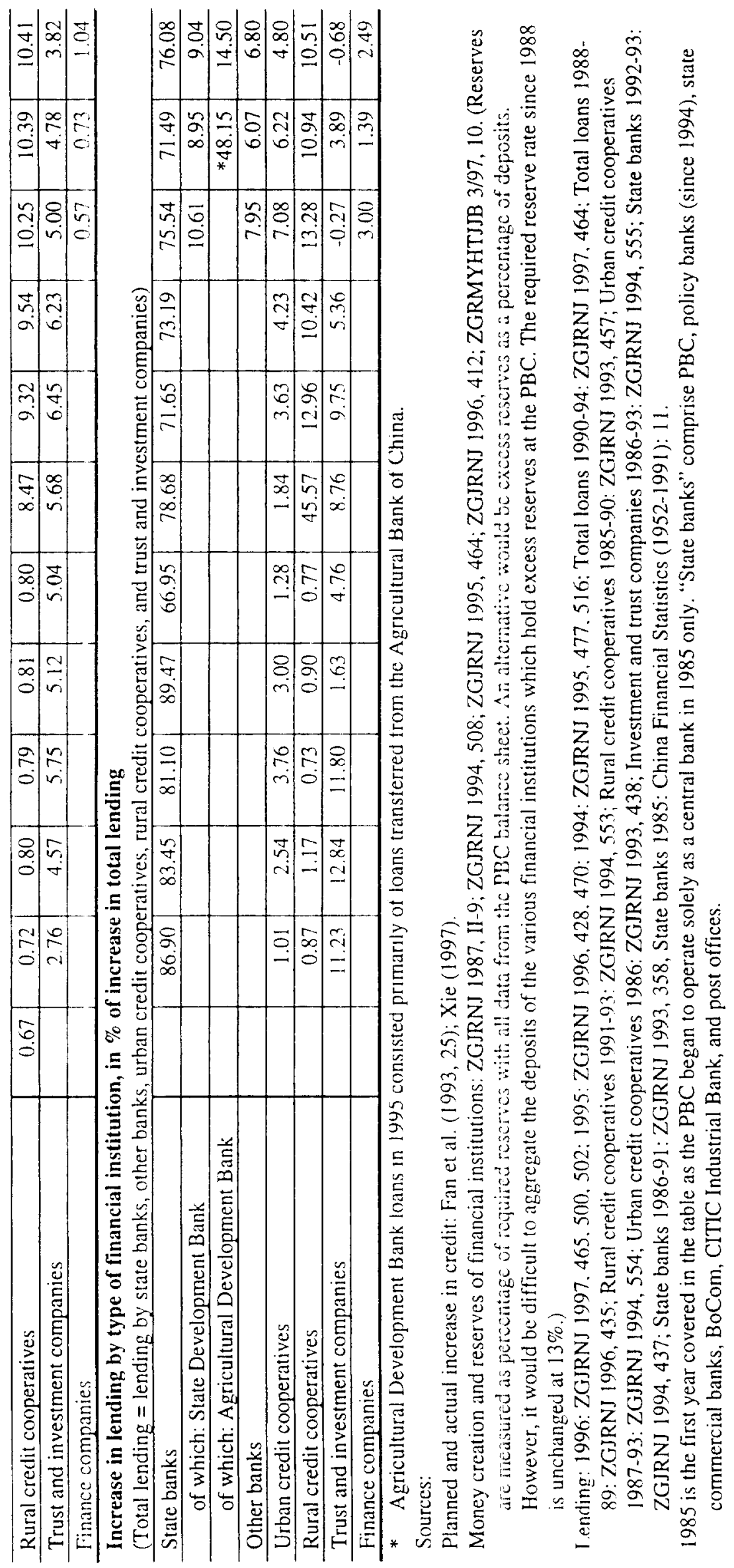

